\title{
PERSEPSI KONSUMEN YANG BERBELANJA KOMODITI PERTANIAN PADA SUPERMARKET DI KOTA MANADO
}

\author{
Deliana Bihuku \\ Grace Adonia Josefina Rumagit \\ Caroline B. D. Pakasi
}

\begin{abstract}
This research aims to describe consumer perceptions based on the attributes of ease in shopping, product, price, physical character, and service to agricultural commodities consumers shopping at Supermarket in Manado City. The data collected were analyzed descriptively and presented in tabular form and cross tabulation. The study was conducted for three months from October 2017 until December 2017 in three supermarkets namely Multimart Manado, Hypermart Mantos, and Transmart Carrefour. The data used is the primary data obtained through interviews to 90 respondents who have been shopping for agricultural commodities in Supermarket in October 2017. The results of research showed that the perception of consumers who shop for agricultural commodities in supermarkets in Manado City against the five attributes that influence it, including in the category strongly agrre (54.7\%), agree (41.8\%), neutral (3.5\%), while categories disagree and strongly disagree was not selected. Of the categories strongly agree, product attributes ranks first (60.4\%), followed by the situation attributes (57.4\%), service attributes (56.3\%), ease of shopping attributes (50.7\%), and final position price attributes (48.9\%).
\end{abstract}

Keywords: consumer behavior, perception, shopping, supermarkets, agricultural commodities, Manado City

\begin{abstract}
ABSTRAK
Penelitian ini bertujuan untuk mendeskripsikan persepsi konsumen berdasarkan atribut kemudahan dalam berbelanja, produk, harga, fisik swalayan, dan pelayanan pada konsumen komoditi pertanian yang berbelanja di Supermarket di Kota Manado. Data yang dikumpulkan dianalisis secara deskriptif dan disajikan dalam bentuk tabel dan tabulasi silang. Penelitian dilaksanakan selama tiga bulan dari Oktober 2017 sampai Desember 2017 pada tiga supermarket yaitu Multimart Manado, Hypermart Mantos, dan Transmart Carrefour. Data yang digunakan adalah data primer yang diperoleh melalui wawancara kepada 90 responden yang telah berbelanja komoditi pertanian di Supermarket pada Bulan Oktober 2017. Hasil penelitian menunjukkan bahwa persepsi konsumen yang berbelanja komoditi pertanian pada supermarket di Kota Manado terhadap kelima atribut yang mempengaruhinya, termasuk dalam kategori sangat setuju $(54,7 \%)$, setuju $(41,8 \%)$, netral $(3,5 \%)$, sedangkan kategori tidak setuju dan sangat tidak setuju tidak dipilih. Dari kategori sangat setuju, atribut produk menempati urutan pertama $(60,4 \%)$, diikuti atribut fisik swalayan $(57,4 \%)$, atribut pelayanan $(56,3 \%)$, atribut kemudahan dalam berbelanja $(50,7 \%)$, dan posisi akhir atribut harga $(48,9 \%)$.
\end{abstract}

Kata kunci: perilaku konsumen, persepsi, berbelanja, supermarket, komoditi pertanian, Kota Manado 


\section{PENDAHULUAN}

\section{Latar Belakang}

Perilaku konsumen berkaitan dengan produsen maupun penyedia produk yang lengkap untuk dapat meningkatkan keuntungan usaha dan juga kepuasan konsumen. Konsumen yang merasa puas tentu akan meningkatkan perilaku pembeliannya, baik frekuensi maupun intensitas pembelian yang dilakukan. Konsumen saat ini lebih pandai dalam memilih tempat berbelanja dengan fungsi fasilitas dan kemudahan dalam yang disediakan.

Perkembangan pasar modern saat ini sangat pesat, yang menawarkan kemudahan, kenyamanan, dan keamanan bagi konsumen untuk memenuhi kebutuhan sehari-hari secara mudah dan efisien. Hal tersebut menghadirkan berbagai macam ruang yang hadir dengan berbagai macam bentuk pula mulai dari warung, toko, ruko, pasar, departemen store, plaza, town square, trade centre, shopping centre, supermarket sampai dengan minimart.

Kota Manado dengan pembangunan yang begitu pesat sehingga dimana-mana terdapat tempat perbelanjaan seperti Transmart Carrefour yang merupakan retail skala internasional, Hypermart termasuk supermarket yang memiliki banyak cabang di Indonesia dan termasuk dalam skala jaringan nasional, dan supermarket skala lokal seperti Multimart karena belum berdiri di semua kota di Indonesia.

Menurut Engel F. et aldalam Riorini (2001) menyatakan determinan keputusan tentang pilihan toko bervariasi menurut pangsa pasar dan menurut kelas produk. Atribut yang mencolok/determinan biasanya masuk ke dalam kategori berikut :

(1) Lokasi

(2) Sifat dan kualitas keragaman

(3) Harga

(4) Iklan dan promosi

(5) Personel penjualan

(6) Pelayanan yang diberikan

(7) Atribut fisik toko

(8) Sifat pelanggan

(9) Atmosfer toko dan

(10) Pelayanan dan kepuasan sesudah transaksi.
Atribut-atribut yang tersebut merupakan karakteristik pasar dan menjadi pertimbangan konsumen dalam keputusan berbelanja.

Proses pemilihan tempat berbelanja tertentu merupakan fungsi dari karakteristik konsumen dan karateristik tempat berbelanja. Dengan kata lain, tiap pangsa pasar konsumen berbelanja akan memiliki suatu citra dari berbagai tempat berbelanja. Konsumen memilah-milah atau membanding-bandingkan karakteristik tempat berbelanja untuk kemudahan seperti lokasi, harga, produk, situasi, dan pelayanan.

Komoditi pertanian termasuk produk kebutuhan pokok sehari-hari seperti produk pangan, sayuran, dan buah-buahan dan dapat diperoleh di pasar tradisional maupun di pasar modern biasa dikenal produk segar. Konsumen akan melihat suatu produk berdasarkan karakteristik, ciri, dan bentuk produk tersebut serta manfaat bagi kesehatannya sebelum ia mengambil keputusan untuk berbelanja.

Konsumen selain berbelanja di supermarket, sudah menjadi kebiasaan untuk rekreasi karena fasilitas fisik pasar modern. Tersedianya produk lain (produk non pertanian) turut mempengaruhi seseorang berbelanja ke supermarket, dan apabila konsumen merasa nilai yang dirasakan lebih tinggi daripada yang diharapkan maka konsumen akan merasa puas dan cenderung akan loyal. Konsumen yang merasa puas tentu akan meningkatkan perilaku pembeliannya, baik frekuensi maupun intensitas pembelian yang dilakukan.

\section{Perumusan Masalah}

Berdasarkan latar belakang di atas, maka yang menjadi masalah dalam penelitian ini adalah bagaimana persepsi konsumen yang berbelanja komoditi pertanian pada supermarket di Kota Manado?

\section{Tujuan Penelitian}

Penelitian ini bertujuan untuk mendeskripsikan persepsi konsumen yang berbelanja komoditi pertanian pada supermarket di Kota Manado. 


\section{Manfaat Penelitian}

Bagi perusahaan, penelitian ini diharapkan membantu perusahaan dalam mengidentifikasikan perilaku konsumen terutama dalam pengambilan keputusan. Bagi peneliti, hasil dari penelitian ini diharapkan akan menambah wawasan tentang perilaku konsumen yaitu mengetahui persepsi konsumen dalam memilih tempat berbelanja. Bagi pembaca, sebagai bahan acuan untuk penelitian selanjutnya yang sesuai dengan topik penelitian ini dan dapat dijadikan referensi kajian dalam bidang penelitian serupa.

\section{METODOLOGI PENELITIAN}

\section{Waktu dan Tempat Penelitian}

Penelitian ini dilaksanakan selama 3 (tiga) bulan dari Oktober sampai Desember 2017, mulai dari persiapan sampai penyusunan laporan. Tempat penelitian pada tiga supermarket berdasarkan skala jaringannya, yaitu Multimart Manado dalam skala lokal, Hypermart Mantos dalam skala nasional, dan Transmart Carrefour Manado dalam skala internasional. Ketiga supermarket ini diasumsikan dapat mewakili supermarket yang ada di Kota Manado serta terdapat beragam komoditi pertanian yang dijual didalamnya.

\section{Metode Pengumpulan Data}

Data yang digunakan dalam penelitian ini adalah data primer dan data sekunder.Data primer yaitu wawancara langsung dengan konsumen yang berbelanja komoditi pertanian dan data sekunder diperoleh dari literatur yang berkaitan dengan penelitian ini.Alat instrumen dalam penelitian ini adalah menggunakan kuisioner dan penyusunan kuisioner menggunakan skala yang mengacu pada skala likert dengan indeks nilai dari 1 sampai 5.

\section{Metode Penarikan Sampel}

Penarikan sampel dilakukan dengan menggunakan metode accidental sampling (sampling secara kebetulan) yaitu konsumen yang sedang atau telah berbelanja komoditi pertanian di ketiga supermarket ini dan bersedia untuk diwawancarai.Jumlah sampel yang diambil sebanyak 90 responden terdiri dari 30 responden di Transmart Carrefour, 30 responden di Hypermart Mantos, dan 30 responden di Multimart Manado.

\section{Konsepsi Pengukuran Variabel}

1) Karakteristik Konsumen

a) Jenis kelamin (Laki-laki/Perempuan)

b) Umur (Tahun)

c) Pendidikan terakhir (SD, SMP, SMA, Perguruan Tinggi)

d) Pekerjaan (Pelajar/Mahasiswa, Pegawai Swasta, PNS, IRT, Wiraswasta, Lainlain)

e) Pendapatan (Rp/bulan)

f) Frekuensi kunjungan (1-2 kali, 3-5 kali, $>5$ kali per minggu)

g) Jenis produk pertanian yang sering dibeli (buah-buahan, sayuran, beras, daging dan ikan)

2) Atribut-atribut yang Mempengaruhi Konsumen Berbelanja di Supermarket. Engel F. et al dalam Riorini (2001) menyatakan determinan keputusan tentang pilihan toko bervariasi menurut pangsa pasar dan menurut kelas produk.

1. Kemudahan dalam berbelanja
a) Lokasi yang strategis
b) Sarana transportasi mudah dan lancar
c) Tersedianya tempat parkir

\section{Produk}
a) Keanekaragaman produk
b) Penempatan produk
c) Mutu dan kesegaran produk

3. Harga
a) Harga terjangkau
b) Harga sesuai mutu produk
c) Adanya potongan harga

4. Fisik Swalayan
a) Tata letak ruang
b) Kebersihan ruangan
c) Tampilan ruangan menarik

5. Pelayanan
a) Pelayanan cepat
b) Karyawan cermat dan handal
c) Memuaskan penuh perhatian

3) Jumlah Kunjungan
a) Kategori 3 yaitu konsumen yang berbelanja $>5$ kali per minggu
b) Kategori 2 yaitu konsumen yang berbelanja 3-5 kali per minggu
c) Kategori 1 yaitu konsumen yang berbelanja 1-2 kali per minggu




\section{Metode Analisis Data}

Data yang dikumpulkan dalam penelitian ini dianalisis secara deskriptif, dan disajikan dalam bentuk tabel dan tabulasi silang.

\section{HASIL DAN PEMBAHASAN}

\section{Gambaran Umum Tempat Penelitian}

Transmart Carrefour Manado

Transmart Carrefour Star Square Manado di Sulawesi Utara mulai dibuka Juli 2017, gerai yang ke-99 ber-alamat di Jalan Walter Monginsidi, Bahu Malalayang Kota Manado.

Tahun yang sama pada bulan November dibuka gerai ke-2 di Grand Kawanua City Walk. Transmart Carrefour Star Square Manado berada di lokasi yang strategis sehingga memudahkan dalam aksesibilitas dan kemudahan-kemudahan dalam berbelanja, juga terdapat berbagai promo menarik kepada pelanggan yang berbelanja menggunakan kartu member Bank Mega.

Perusahaan dagang Carrefour dibentuk tahun 1959 oleh keluarga Fournier dan Defforey, disusul dengan pembukaan supermarket Carrefour kemudian di Kota Annecy, wilayah sebelah timur Perancis. Tahun 1973, Carrefour membuka cabang pertama di luar negeri, yaitu di Spanyol. Carrefour Indonesia memulai sejarahnya di Indonesia pada bulan Oktober 1998 dengan membuka unit pertama di Cempaka Putih.

\section{Hypermart Manado Town Square}

Hypermart adalah jaringan supermarket yang memiliki banyak cabang di Indonesia. Pemilik usaha ritel ini adalah Matahari Putra Prima dengan Presiden Camelito J. Regalado dan kantor pusatnya yaitu di Jakarta. Dengan trademark Hyper, yang kini sahamnya dimiliki oleh PT. Matahari Putra Prima Tbk. Saat ini Hypermart sudah memiliki 100 gerai di Indonesia.Di Indonesia hampir seluruh kota telah ada hypermart lebih dari satu gerai, seperti di Kota Manado terdapat tiga cabang gerai yaitu Hypermart Mantos, Hypermart MTC Manado, dan Hypermart Kairagi. Dari tiga gerai tersebut, Hypermart Mantos berada di daerah strategis karena Mantos merupakan landmark Kota Manado.

\section{Multimart Manado}

Multimart Manado merupakan suatu usaha ritel yang bergerak di bidang pasar swalayan yang biasa disebut supermarket, dimana supermarket ini menjual kebutuhan pokok produk segar pertanian dan non pertanian dan peralatan rumah tangga lainnya serta menyediakan restoran. Multimart dengan perusahaan PT. Multi Citra Abadi di Jl. Sam Ratulangi Manado pertama kali berdiri di pada tahun 2004 sampai saat ini masih tetap merupakan supermarket skala lokal. Multimart dengan strategi pemasarannya yaitu menjunjung tinggi semboyang "Kami Memang Beda" serta dengan memberikan kartu member Multimart.

\section{Karakteristik Responden}

Hasil deskripsi responden dari pengumpulan data melalui kuesioner yang dilakukan kepada para konsumen yang sedang membeli produk pertanian segar (sayuran, buah-buahan, produk perikanan dan daging) pada 3 (tiga) supermarket yangdipilih berdasarkan skala jaringannya. Jumlah reponden sebanyak 90 orang dengan 30 responden pada masing-masing supermarket.Hubungan antara karekteristik reponden dengan frekuensi pembelian di Transmart Carrefour, Hypermart Mantos, dan Multimart Manado diolah dengan menggunakan analisis crosstabs.Hubungan antara karakteristik konsumen dengan frekuensi kunjungan di Transmart Carrefour Star Square Manado dapat dilihat pada Tabel 1.

Tabel 1. Karakteristik Responden dengan Frekuensi Kunjungan Konsumen

\begin{tabular}{|c|c|c|c|c|c|}
\hline \multirow[t]{2}{*}{ Karakteristik } & \multicolumn{3}{|c|}{$\begin{array}{c}\text { Frekuensi kunjungan per } \\
\text { minggu }\end{array}$} & \multirow[t]{2}{*}{ Total } & \multirow[t]{2}{*}{ Persentase } \\
\hline & $1-2$ & $3-5$ & $>5$ & & \\
\hline \multicolumn{6}{|l|}{ Usia } \\
\hline$\leq 20$ tahun & 1 & 2 & 0 & 3 & 10 \\
\hline $21-30$ tahun & 3 & 4 & 1 & 8 & 26.67 \\
\hline $31-40$ tahun & 7 & 3 & 1 & 11 & 36.67 \\
\hline 41-50 tahun & 3 & 1 & 1 & 5 & 16.67 \\
\hline$>50$ tahun & 2 & 1 & 0 & 3 & 10 \\
\hline Jumlah & 16 & 11 & 3 & 30 & 100 \\
\hline \multicolumn{6}{|l|}{ Jenis Kelamin } \\
\hline Laki-laki & 5 & 4 & 2 & 11 & 36.67 \\
\hline Perempuan & 11 & 7 & 1 & 19 & 63.33 \\
\hline Jumlah & 16 & 11 & 3 & 30 & 100 \\
\hline \multicolumn{6}{|l|}{ Pendidikan } \\
\hline SD & 1 & 0 & 0 & 1 & 3.33 \\
\hline SMP & 1 & 0 & 1 & 2 & 6.67 \\
\hline SMA/SMK & 4 & 4 & 2 & 10 & 33.33 \\
\hline Sarjana & 10 & 7 & 0 & 17 & 56.67 \\
\hline Jumlah & 16 & 11 & 3 & 30 & 100 \\
\hline \multicolumn{6}{|l|}{ Pekerjaan } \\
\hline Pelajar/Mahasiswa & 3 & 3 & 0 & 6 & 30 \\
\hline Wiraswasta & 2 & 1 & 0 & 3 & 23.33 \\
\hline Pegawai Swasta & 2 & 1 & 1 & 4 & 13.33 \\
\hline Karyawan & 2 & 2 & 1 & 5 & 16.67 \\
\hline PNS & 2 & 2 & 0 & 4 & 13.33 \\
\hline IRT & 4 & 2 & 1 & 7 & 17.67 \\
\hline Lain-lain & 1 & 0 & 0 & 1 & 3.33 \\
\hline Jumlah & 16 & 11 & 3 & 30 & 100 \\
\hline \multicolumn{6}{|l|}{ Pendapatan } \\
\hline$\leq$ Rp. 2 juta & 4 & 2 & 1 & 7 & 33.33 \\
\hline Rp. 2-5 juta & 5 & 5 & 2 & 12 & 40 \\
\hline$>$ Rp. 5 juta & 7 & 4 & 0 & 11 & 36.67 \\
\hline Jumlah & 16 & 11 & 3 & 30 & 100 \\
\hline
\end{tabular}


Berdasarkan Tabel 1 Responden Carrefour sebagian besar berusia 31-40 tahun dengan jumlah 11 responden atau 36.67 persen. Berdasarkan jenis kelamin sebagian besar adalah perempuan dengan jumlah 19 responden atau 63.33 persen. Untuk tingkat pendidikan terakhir sarjana sebanyak 17 responden atau 56.67 persen. Jenis pekerjaan terbanyak yaitu Ibu Rumah Tangga sebanyak 7 responden atau 17.67 persen. seminggu, dan 1 orang dengan frekuensi kunjungan $>5$ kali dalam seminggu. Responden Carrefour sebagian besar tingkat pendapatan > Rp.2-5 juta sebanyak 12 responden atau 40 persen. Sedangkan jumlah kunjungan terbanyak 1-2 kali dalam seminggu.

Hubungan antara karakteristik konsumen dengan frekuensi kunjungan di Hypermart Mantos dapat dilihat pada Tabel 2 berikut ini.

Tabel 2. Karakteristik Responden dengan Frekuensi

\begin{tabular}{lccccr}
\multicolumn{5}{c}{ Kunjungan Konsumen } & Hypermart Mantos \\
\hline \multicolumn{1}{c}{ Karakteristik } & \multicolumn{2}{c}{$\begin{array}{c}\text { Frekuensi kunjungan } \\
\text { per minggu }\end{array}$} & Total & Persentase \\
\hline \multicolumn{7}{c}{} & $\mathbf{1 - 5}$ & $\mathbf{> 5}$ & & \\
\hline Usia & 2 & 2 & 0 & 4 & 13.33 \\
\hline$\leq 20$ tahun & 2 & 3 & 1 & 6 & 20 \\
$21-30$ tahun & 5 & 4 & 1 & 10 & 33.33 \\
$31-40$ tahun & 1 & 4 & 1 & 6 & 20 \\
41-50 tahun & 2 & 2 & 0 & 4 & 13.33 \\
$>$ 50 tahun & $\mathbf{1 2}$ & $\mathbf{1 5}$ & $\mathbf{3}$ & $\mathbf{3 0}$ & $\mathbf{1 0 0}$ \\
\hline Jumlah & & & & & \\
\hline
\end{tabular}

\begin{tabular}{lccccr}
\hline Jenis Kelamin & & & & & \\
\hline Laki-laki & 3 & 4 & 2 & 9 & 30 \\
Perempuan & 9 & 11 & 1 & 21 & 70 \\
\hline Jumlah & $\mathbf{1 2}$ & $\mathbf{1 5}$ & $\mathbf{3}$ & $\mathbf{3 0}$ & $\mathbf{1 0 0}$ \\
\hline
\end{tabular}

\begin{tabular}{lccccr}
\hline Pendidikan & & & & & \\
\hline SD & 1 & 1 & 0 & 2 & 6.67 \\
SMP & 1 & 1 & 0 & 2 & 6.67 \\
SMA/SMK & 4 & 6 & 1 & 11 & 36.67 \\
Sarjana & 6 & 8 & 1 & 15 & 50 \\
\hline Jumlah & $\mathbf{1 2}$ & $\mathbf{1 5}$ & $\mathbf{3}$ & $\mathbf{3 0}$ & $\mathbf{1 0 0}$ \\
\hline & & & & & \\
\hline Pekerjaan & & & & & \\
\hline Pelajar/Mahasiswa & 4 & 2 & 0 & 6 & 20 \\
Wiraswasta & 2 & 2 & 1 & 5 & 30 \\
Pegawai Swasta & 1 & 3 & 0 & 4 & 13.33 \\
Karyawan & 0 & 2 & 2 & 4 & 13.33 \\
PNS & 1 & 2 & 0 & 3 & 16.67 \\
IRT & 2 & 4 & 0 & 6 & 20 \\
Lain-lain & 2 & 0 & 0 & 2 & 6.67 \\
\hline Jumlah & $\mathbf{1 2}$ & $\mathbf{1 5}$ & $\mathbf{3}$ & $\mathbf{3 0}$ & $\mathbf{1 0 0}$ \\
\hline & & & & & \\
\hline Pendapatan & & & & & \\
\hline$\leq$ Rp. 2 juta & 7 & 2 & 1 & 10 & 33.33 \\
Rp. 2-5 juta & 3 & 10 & 2 & 15 & 50 \\
$>$ Rp. 5 juta & 2 & 3 & 0 & 5 & 16.67 \\
\hline Jumlah & $\mathbf{1 2}$ & $\mathbf{1 5}$ & $\mathbf{3}$ & $\mathbf{3 0}$ & $\mathbf{1 0 0}$ \\
\hline
\end{tabular}

Berdasarkan Tabel 2, responden Hypermart Mantos sebagian besar berusia 3140 tahun dengan jumlah 10 responden atau 33.33 persen. Responden terbanyak berjenis kelamin perempuan dengan jumlah 21 responden atau 70 persen. Tingkat pendidikan sebagian besar adalah sarjana sebanyak 15 responden atau 50 persen. Jenis pekerjaan, jumlah responden Hypermart Mantos dengan pekerjaan Ibu Rumah Tangga adalah sebanyak 6 responden atau 20 persen. Tingkat pendapatan > Rp. 2-5 juta sebanyak 15 responden.

Hubungan antara karakteristik konsumen dengan frekuensi kunjungan di Multimart Manado dapat dilihat pada Tabel 3.

Tabel 3. Karakteristik Responden dengan Frekuensi Kunjungan Konsumen Multimart Manado

\begin{tabular}{lccccr}
\hline Karakteristik & $\begin{array}{c}\text { Frekuensi kunjungan } \\
\text { per minggu }\end{array}$ & Total & Persentase \\
\hline \multicolumn{7}{c}{$\mathbf{1 - 2}$} & $\mathbf{3 - 5}$ & $\mathbf{> 5}$ & & \\
\hline Usia & & & & & 10 \\
\hline$\leq 20$ tahun & 2 & 1 & 0 & 3 & 2.33 \\
21-30 tahun & 3 & 2 & 1 & 6 & 26.67 \\
31-40 tahun & 4 & 3 & 1 & 8 & 30 \\
41-50 tahun & 5 & 4 & 0 & 9 & 13.33 \\
$>50$ tahun & 1 & 2 & 0 & 4 & $\mathbf{1 0 0}$ \\
\hline Jumlah & $\mathbf{1 5}$ & $\mathbf{1 3}$ & $\mathbf{2}$ & $\mathbf{3 0}$ & \\
\hline
\end{tabular}

\begin{tabular}{lccccr}
\hline $\begin{array}{l}\text { Jenis } \\
\text { Kelamin }\end{array}$ & & & & & \\
\hline Laki-laki & 6 & 1 & 0 & 7 & 23.33 \\
Perempuan & 9 & 12 & 0 & 23 & 76.67 \\
\hline Jumlah & $\mathbf{1 5}$ & $\mathbf{1 3}$ & $\mathbf{2}$ & $\mathbf{3 0}$ & $\mathbf{1 0 0}$ \\
\hline
\end{tabular}

\begin{tabular}{|c|c|c|c|c|c|}
\hline Pendidikan & & & & & \\
\hline SD & 1 & 1 & 0 & 2 & 6.67 \\
\hline SMP & 1 & 2 & 0 & 3 & 10 \\
\hline SMA/SMK & 7 & 4 & 1 & 12 & 40 \\
\hline Sarjana & 6 & 6 & 1 & 13 & 43.33 \\
\hline Jumlah & 15 & 13 & 2 & 30 & 100 \\
\hline \multicolumn{6}{|l|}{ Pekerjaan } \\
\hline Pelajar/Mahasiswa & 3 & 2 & 0 & 5 & 17.67 \\
\hline Wiraswasta & 3 & 1 & 1 & 5 & $23 . .33$ \\
\hline Pegawai & & & & & \\
\hline Swasta & 2 & 1 & 0 & 3 & 10 \\
\hline Karyawan & 1 & 1 & 0 & 2 & 6.67 \\
\hline PNS & 4 & 1 & 0 & 5 & 17.67 \\
\hline IRT & 1 & 7 & 1 & 9 & 30 \\
\hline Lain-lain & 1 & 0 & 0 & 1 & 3.33 \\
\hline Jumlah & 15 & 13 & 2 & 30 & 100 \\
\hline \multicolumn{6}{|l|}{ Pendapatan } \\
\hline$\leq$ Rp. 2 juta & 6 & 3 & 1 & 9 & 30 \\
\hline Rp. 2-5 juta & 6 & 8 & 1 & 15 & 50 \\
\hline$>$ Rp. 5 juta & 3 & 2 & 0 & 6 & 20 \\
\hline Jumlah & 15 & 13 & 2 & 30 & 100 \\
\hline
\end{tabular}


Berdasarkan Tabel 3, sebagian besar responden Multimart Manado berusia 41-50 tahun dengan jumlah 9 responden atau 30 persen. Berdasarkan jenis kelamin, sebagian besar berjenis kelamin perempuan dengan jumlah 23 responden atau 76.67 persen. Tingkat pendidikan responden yaitu sarjana sebanyak 13 responden atau 43.33 persen. Berdasarkan jenispekerjaan, di sebagian besar yaitu ibu rumah tangga sebanyak 9 responden atau 30 persen, sedangkan tingkat pendapatan > Rp.2-5 juta sebanyak 15 responden atau 50 persen.

\section{Jenis Komoditi Pertanian yang dibeli di Transmart Carrefour, Hypermart Mantos, dan Multimart Manado}

Komoditi pertanian yang tersedia di supermarket seperti buah-buahan, sayuran, beras, daging dan ikan, serta bumbu dapur lainnya dengan bentuk yang segar dan beraneka macam jenis. Tabel 4 mengenai daftar komoditi pertanian yang sering dibeli konsumen di Transmart Carrefour, Hypermart Mantos, dan Multimart Manado.

\begin{tabular}{|c|c|c|c|c|c|}
\hline \multirow[b]{2}{*}{ No } & \multicolumn{5}{|c|}{ Supermarket } \\
\hline & $\begin{array}{c}\text { Produk } \\
\text { Pertanian }\end{array}$ & $\begin{array}{l}\text { Transmart } \\
\text { Carrefour }\end{array}$ & $\begin{array}{r}\text { Hypermart } \\
\text { Mantos }\end{array}$ & $\begin{array}{c}\text { Multimart } \\
\text { Manado }\end{array}$ & $\begin{array}{c}\text { Jenis } \\
\text { produk }\end{array}$ \\
\hline 1. & $\begin{array}{l}\text { Buah- } \\
\text { buahan }\end{array}$ & $\begin{array}{l}\text { Apel, } \\
\text { semangka, } \\
\text { anggur, pir, } \\
\text { lengkeng, } \\
\text { buah naga, jeruk } \\
\text { sunkist, jeruk } \\
\text { manis, mangga, } \\
\text { durian, pepaya, } \\
\text { avokad, pisang. }\end{array}$ & $\begin{array}{l}\text { Apel fuji, } \\
\text { anggur, } \\
\text { semangka, } \\
\text { psang, pepaya, } \\
\text { apel merah, } \\
\text { mangga, pir. }\end{array}$ & $\begin{array}{l}\text { Apel merah, } \\
\text { apel fuji, apel } \\
\text { hijau, nanas, } \\
\text { pisang, } \\
\text { mangga, jeruk } \\
\text { manis, jeruk } \\
\text { sunkist,buah } \\
\text { naga, } \\
\text { semangka, } \\
\text { anggur, melon, } \\
\text { salak, pepaya. }\end{array}$ & $>10$ \\
\hline 2. & Sayuran & $\begin{array}{l}\text { Kangkung, } \\
\text { bunga kol, } \\
\text { petsay, seledri, } \\
\text { kol ungu, } \\
\text { brokoli, wortel, } \\
\text { kentang, cabai, } \\
\text { tomat, bawang } \\
\text { merah, bawang } \\
\text { putih, sayur } \\
\text { gedi, sayur } \\
\text { pakis, sawi, } \\
\text { bayam, timun } \\
\text { jepang, bunga } \\
\text { pepaya. }\end{array}$ & $\begin{array}{l}\text { Petsay, } \\
\text { bayang, } \\
\text { kangkung, } \\
\text { sawi, buncis, } \\
\text { kol, bunga kol, } \\
\text { bawang, cabai, } \\
\text { tomat, sayur } \\
\text { gedi, bunga } \\
\text { pepaya, jagung } \\
\text { manis, baby } \\
\text { corn. }\end{array}$ & $\begin{array}{l}\text { Kangkung, } \\
\text { sayur pakis, } \\
\text { cabai, daun ubi, } \\
\text { bunga pepaya, } \\
\text { sayur gedi, } \\
\text { kentang, wortel, } \\
\text { timun, bayam, } \\
\text { sawi, buncis, } \\
\text { daun bawang, } \\
\text { daun pandan, } \\
\text { jagung, } \\
\text { mentimun } \\
\text { jepang, sayur } \\
\text { kol, bawang } \\
\text { merah, bawang } \\
\text { putih, cabai. }\end{array}$ & $>10$ \\
\hline 3. & Beras & $\begin{array}{l}\text { Beras tawon, } \\
\text { superwin, beras } \\
\text { merah, beras } \\
\text { ketan, pandan } \\
\text { wangi, beras } \\
\text { hitam, beras } \\
\text { kota } \\
\text { kotamobagu. }\end{array}$ & $\begin{array}{l}\text { Beras tawon, } \\
\text { superwin, } \\
\text { beras merah, } \\
\text { beras ketan, } \\
\text { pandan wangi, } \\
\text { beras hitam, } \\
\text { beras } \\
\text { membramo. }\end{array}$ & $\begin{array}{l}\text { Beras superwin, } \\
\text { beras merah, } \\
\text { beras ketan, } \\
\text { pandan wangi, } \\
\text { beras hitam, } \\
\text { beras kota } \\
\text { kotamobagu. }\end{array}$ & $>10$ \\
\hline 4. & $\begin{array}{l}\text { Daging dan } \\
\text { ikan }\end{array}$ & $\begin{array}{l}\text { Daging ayam, } \\
\text { daging sapi, } \\
\text { daging babi, } \\
\text { ikan tuna, ikan } \\
\text { nike, ikan } \\
\text { cakalang, ikan } \\
\text { oci, ikan mujair, } \\
\text { nila. }\end{array}$ & $\begin{array}{l}\text { Daging sapi, } \\
\text { daging babi, } \\
\text { ayam, ikan } \\
\text { lele, ikan } \\
\text { mujair, ikan } \\
\text { tuna, cakalang. }\end{array}$ & $\begin{array}{l}\text { Daging ayam, } \\
\text { Ikan cakalang, } \\
\text { ikan mujair, } \\
\text { ikan tuna, ikan } \\
\text { oci, daging } \\
\text { sapi, ikan nike, } \\
\text { ikan nila. }\end{array}$ & $>10$ \\
\hline
\end{tabular}

Berdasarkan Tabel 4 mengenai jenis komoditi pertanian yang sering dibeli responden yang berbelanja pada Carrefour, Hypermart, dan Multimart sebagian besar membeli buah-buahan. Jenis produk di supermarket rata-rata lebih dari sepuluh jenis komoditi pertanian.

\section{Atribut-atribut yang Mempengaruhi Konsumen Berbelanja diSupermarket}

\section{Kemudahan dalam Berbelanja}

Atribut kemudahan dalam berbelanja terdiri dari lokasi yang strategis, transportasi lancar, dan tersedianya tempat parkir.

\section{Lokasi Strategi}

Lokasi dimana pusat perbelanjaan itu dibangun dekat dengan pusat perbelanjaan yang lain sehingga akan sangat mempengaruhi minat masyarakat untuk mengunjungi pusat perbelanjaan tersebut, karena masyarakat berpikir biaya transportasi mudah untuk akses ke pusat perbelanjaan yang lain. Persepsi responden mengenai lokasi strategis jumlah kunjungan berdasarkan skala supermarket dapat dilihat pada Tabel 5.

Tabel 5. Lokasi Strategis

\begin{tabular}{|c|c|c|c|c|c|c|c|}
\hline \multirow{2}{*}{ Supermarket } & \multirow{2}{*}{ Kategori } & \multirow{2}{*}{ Responden } & \multicolumn{5}{|c|}{ Persepsi Konsumen } \\
\hline & & & SS & S & $\mathbf{N}$ & TS & STS \\
\hline \multirow{3}{*}{$\begin{array}{l}\text { Transmart } \\
\text { Carrefour }\end{array}$} & 1 & 16 & 7 & 9 & 0 & 0 & 0 \\
\hline & 2 & 11 & 6 & 5 & 0 & 0 & 0 \\
\hline & 3 & 3 & 3 & 0 & 0 & 0 & 0 \\
\hline Jumlah & & 30 & 16 & 14 & $\mathbf{0}$ & $\mathbf{0}$ & $\mathbf{0}$ \\
\hline \multirow{3}{*}{$\begin{array}{l}\text { Hypermart } \\
\text { Mantos }\end{array}$} & 1 & 13 & 8 & 5 & 0 & 0 & 0 \\
\hline & 2 & 12 & 5 & 6 & 1 & 0 & 0 \\
\hline & 3 & 5 & 3 & 2 & 0 & 0 & 0 \\
\hline Jumlah & & 30 & 16 & 13 & 1 & $\mathbf{0}$ & $\mathbf{0}$ \\
\hline \multirow{3}{*}{$\begin{array}{l}\text { Multimart } \\
\text { Manado }\end{array}$} & 1 & 14 & 5 & 8 & 1 & 0 & 0 \\
\hline & 2 & 11 & 5 & 5 & 1 & 0 & 0 \\
\hline & 3 & 5 & 2 & 3 & 0 & 0 & 0 \\
\hline Jumlah & & 30 & 12 & 16 & 2 & $\mathbf{0}$ & $\mathbf{0}$ \\
\hline Total & & 90 & 46 & 41 & 3 & 0 & 0 \\
\hline Persentase (\%) & & 100 & 51.11 & 45.56 & 3.33 & 0 & 0 \\
\hline
\end{tabular}

Berdasarkan Tabel 5 persepsi konsumen mengenai lokasi yang strategis dan mudah dijangkau, sebagian besar sangat setuju yaitu sebesar $51.11 \%$ bahwa letak lokasi tiga supermarket strategis dan mudah dijangkau. Terlihat bahwa konsumen memilih berbelanja pada supermarket karena dekat dengan pusat perbelanjaan dan tersedianya produk lain. 


\section{Transportasi Lancar}

Frekuensi jumlah kunjungan konsumen untuk berbelanja di supermarket, erat kaitannya dengan aksesibilitas kelancaran transportasi. Tanggapan konsumen mengenai transortasi lancar dapat dilihat pada Tabel 6 .

Tabel 6. Transportasi lancar

\begin{tabular}{lllllllc}
\hline Supermarket & Kategori & Responden & \multicolumn{5}{c}{ Persepsi Konsumen } \\
\hline & & & SS & S & N & TS & STS \\
\hline Transmart & 1 & 16 & 5 & 10 & 0 & 0 & 0 \\
Carrefour & 2 & 11 & 5 & 6 & 0 & 0 & 0 \\
& 3 & 3 & 2 & 1 & 0 & 0 & 0 \\
\hline Jumlah & & $\mathbf{3 0}$ & $\mathbf{1 2}$ & $\mathbf{1 7}$ & $\mathbf{0}$ & $\mathbf{0}$ & $\mathbf{0}$ \\
\hline & & & & & & & \\
\hline Hypermart & 1 & 13 & 5 & 7 & 1 & 0 & 0 \\
Mantos & 2 & 12 & 6 & 6 & 0 & 0 & 0 \\
& 3 & 5 & 3 & 2 & 0 & 0 & 0 \\
\hline Jumlah & & $\mathbf{3 0}$ & $\mathbf{1 4}$ & $\mathbf{1 5}$ & $\mathbf{1}$ & $\mathbf{0}$ & $\mathbf{0}$ \\
\hline & & & & & & & \\
\hline Multimart & 1 & 13 & 5 & 7 & 1 & 0 & 0 \\
Manado & 2 & 12 & 6 & 6 & 0 & 0 & 0 \\
& 3 & 5 & 3 & 2 & 0 & 0 & 0 \\
\hline Jumlah & & $\mathbf{3 0}$ & $\mathbf{1 3}$ & $\mathbf{1 6}$ & $\mathbf{1}$ & $\mathbf{0}$ & $\mathbf{0}$ \\
\hline \multicolumn{2}{l}{ Total } & & & & & & \\
\hline Persentase (\%) & & $\mathbf{1 0 0}$ & $\mathbf{4 5 . 5 6}$ & $\mathbf{5 1 . 1 1}$ & $\mathbf{3 . 3 3}$ & $\mathbf{0}$ & $\mathbf{0}$ \\
\hline
\end{tabular}

Berdasarkan Tabel 6 menunjukan bahwa sebagian besar responden setuju sebanyak 46 orang responden dari 90 responden mengenai transportasi lancar ke supermarket Transmart Carrefour, Hypermart Mantos, dan Multimart, sebagian besar konsumen setuju bahwa transportasi menuju supermarket lancar dan aksesibilitasnya mudah dijangkau yaitu sebesar 51.11 persen. Konsumen dalam berbelanja, mereka mempertimbangkan jarak, waktu tempuh, jalan yang bagus, dekat dengan jalan raya, sehingga konsumen dapat menggunakan kendaraan pribadi maupun angkutan umum.

\section{Tersedianya Tempat Parkir}

Salah satu kelebihan supemarket dibandingkan pasar tradisional yaitu tersedianya tempat parkir yang luas dan aman.Konsumen yang memiliki kendaraan pribadi maupun yang menggunakan kendaraan umum lebih menyukai berbelanja ke supermarket karena biasanya tersedia fasilitas basement tempat parkir.Persepsi konsumen mengenai tersedianya tempat parkir dapat dilihat pada Tabel 7.
Tabel 7. Tersedianya Tempat Parkir

\begin{tabular}{llllllll}
\hline Supermarket & Kategori & Responden & \multicolumn{6}{c}{ Persepsi Konsumen } \\
\hline & & & SS & S & N & TS & STS \\
\hline Transmart & 1 & 16 & 6 & 10 & 0 & 0 & 0 \\
Carrefour & 2 & 11 & 5 & 4 & 2 & 0 & 0 \\
& 3 & 3 & 1 & 1 & 1 & 0 & 0 \\
\hline Jumlah & & $\mathbf{3 0}$ & $\mathbf{1 2}$ & $\mathbf{1 5}$ & $\mathbf{3}$ & $\mathbf{0}$ & $\mathbf{0}$ \\
\hline & & & & & & & \\
\hline Hypermart & 1 & 13 & 8 & 5 & 0 & 0 & 0 \\
Mantos & 2 & 12 & 6 & 6 & 0 & 0 & 0 \\
& 3 & 5 & 3 & 2 & 0 & 0 & 0 \\
\hline Jumlah & & $\mathbf{3 0}$ & $\mathbf{1 7}$ & $\mathbf{1 3}$ & $\mathbf{0}$ & $\mathbf{0}$ & $\mathbf{0}$ \\
\hline & & & & & & & \\
\hline Multimart & 1 & 14 & 7 & 7 & 0 & 0 & 0 \\
Manado & 2 & 11 & 4 & 6 & 1 & 0 & 0 \\
& 3 & 5 & 2 & 2 & 1 & 0 & 0 \\
\hline Jumlah & & $\mathbf{3 0}$ & $\mathbf{1 3}$ & $\mathbf{1 5}$ & $\mathbf{2}$ & $\mathbf{0}$ & $\mathbf{0}$ \\
\hline \multicolumn{1}{l}{ Total } & & $\mathbf{9 0}$ & $\mathbf{4 3}$ & $\mathbf{4 1}$ & $\mathbf{6}$ & $\mathbf{0}$ & $\mathbf{0}$ \\
\hline Persentase (\%) & & $\mathbf{1 0 0}$ & $\mathbf{4 7 . 7 8}$ & $\mathbf{4 5 . 5 6}$ & $\mathbf{6 . 6 7}$ & $\mathbf{0}$ & $\mathbf{0}$ \\
\hline
\end{tabular}

Berdasarkan Tabel 7, dilihat dari tanggapan konsumen mengenai tempat parkir, 17 orang dari 30 responden hypermart atau sebesar $56.7 \%$ sangat setuju bahwa lahan parkir luas dan aman. Dilihat dari keseluruhan responden supermarket, 43 responden dari 90 responden (47.8\%) sangat setuju bahwa adanya tempat parkir memudahkan konsumen yang berbelanja khususnya yang menggunakan kendaraan pribadi. Lahan parkir di Transmart Carrefour terdapat 2 pintu masuk, Hypermart Mantos ada 4 pintu dengan basement lahan parkir yang luas dari Mantos 1 sampai Mantos 3, dan Multimart yang dilengkapi basement dengan 2 pintu. Berdasarkan jumlah kunjungan, 41 orang dari 90 responden (45.56 \%) berkunjung 1-2 kali dalam seminggu.Hal ini karena konsumen komoditi pertanian lebih menyukaiberkunjung kesupermarket yang tersedia basement lahan parkir yang luas. Dari jumlah responden yang berkunjung ke supermarket, 20 responden dari 43 responden $(46.5 \%)$ sangat setuju bahwa lahan parkir di supermarket luas dan aman.

Pada atribut kemudahan berbelanja, dalam kuesioner diwakili oleh tiga indikator. Untuk mengetahui jawaban-jawaban responden dapat dilihat pada Tabel 8 .

Tabel 8. Rekapitulasi Tanggapan Responden dengan Atribut Kemudahan Berbelanja

\begin{tabular}{llllllll}
\hline No. & Kategori & \multicolumn{7}{c}{ Persepsi Konsumen } & & Jumlah \\
\hline & & SS & S & N & TS & STS & \\
\hline 1 & Lokasi strategis & 46 & 41 & 3 & 0 & 0 & 90 \\
\hline 2 & Transportasi lancar & 43 & 44 & 3 & 0 & 0 & 90 \\
\hline 3 & $\begin{array}{l}\text { Tersedianya tempat } \\
\text { parkir }\end{array}$ & 44 & 41 & 5 & 0 & 0 & 90 \\
\hline & Jumlah & $\mathbf{1 3 3}$ & $\mathbf{1 2 6}$ & $\mathbf{1 1}$ & $\mathbf{0}$ & $\mathbf{0}$ & $\mathbf{2 7 0}$ \\
\hline & Persentase & $\mathbf{5 0 , 7}$ & $\mathbf{4 3 , 7}$ & $\mathbf{5 , 6}$ & $\mathbf{0}$ & $\mathbf{0}$ & $\mathbf{1 0 0}$ \\
\hline
\end{tabular}


Berdasarkan Tabel 8 tentang rekapitulasi tanggapan responden dengan atribut kemudahan berbelanja dapat dilihat bahwa:

1. Pada pernyataan diatas, tanggapan responden mengenai lokasi yang strategis, dari 90 responden 46 responden menyatakan sangat setuju, 41 responden menyatakan setuju, dan 3 responden menyatakan netral.

2. Pada pernyataan diatas, tanggapan responden mengenai transportasi lancar, dari 90 responden 43 responden menyatakan sangat setuju, 44 responden menyatakan setuju, dan 3 responden menyatakan netral.

3. Pada pernyataan diatas, tanggapan responden mengenai tersedianya tempat parkir, dari 90 responden 44 responden menyatakan sangat setuju, 41 responden menyatakan setuju, 5 responden menyatakan netral.

4. Pada pernyataan diatas, persentase tanggapan responden mengenai atribut kemudahan berbelanja yang, $\quad 50.7 \%$ responden menyatakan sangat setuju, $43.7 \%$ responden menyatakan setuju, dan $5.6 \%$ responden menyatakan netral.

\section{Produk}

Atribut produk terdiri dari keanekaragaman produk, penempatan produk, mutu dan kesegaran produk.

\section{Keanekaragaman Produk}

Frekuensi kunjungan konsumen berbelanja di supermarket erat kaitannya dengan kebutuhan produk atau barang yang ingin dibeli. Produk pertanian di supermarket lebih beragam dan tertata sesuai jenis produk.Persepsi konsumen mengenai keanekaragaman produk dapat dilihat pada Tabel 9.

Tabel 9. Keanekaragaman Produk

\begin{tabular}{llllllll}
\hline Supermarket & Kategori & Responden & \multicolumn{5}{c}{ Persepsi Konsumen } \\
\hline Transmart & 1 & 16 & 9 & 6 & 1 & 0 & 0 \\
Carrefour & 2 & 11 & 7 & 3 & 1 & 0 & 0 \\
& 3 & 3 & 0 & 2 & 1 & 0 & 0 \\
\hline Jumlah & & $\mathbf{3 0}$ & $\mathbf{1 6}$ & $\mathbf{1 1}$ & $\mathbf{3}$ & $\mathbf{0}$ & $\mathbf{0}$ \\
\hline & 1 & 13 & 9 & 4 & 0 & 0 & 0 \\
Hypermart & 2 & 12 & 6 & 4 & 2 & 0 & 0 \\
Mantos & 3 & 5 & 2 & 2 & 1 & 0 & 0 \\
\hline Jumlah & & $\mathbf{3 0}$ & $\mathbf{1 7}$ & $\mathbf{1 0}$ & $\mathbf{3}$ & $\mathbf{0}$ & $\mathbf{0}$ \\
\hline & 1 & 14 & 9 & 5 & 0 & 0 & 0 \\
Multimart & 2 & 11 & 7 & 4 & 0 & 0 & 0 \\
Manado & 3 & 5 & 4 & 1 & 0 & 0 & 0 \\
\hline Jumlah & & $\mathbf{3 0}$ & $\mathbf{2 0}$ & $\mathbf{1 0}$ & $\mathbf{0}$ & $\mathbf{0}$ & $\mathbf{0}$ \\
\hline Total & & $\mathbf{3 0}$ & $\mathbf{5 3}$ & $\mathbf{3 1}$ & $\mathbf{6}$ & $\mathbf{0}$ & $\mathbf{0}$ \\
\hline Persentase (\%) & & $\mathbf{1 0 0}$ & $\mathbf{5 8 . 8 9}$ & $\mathbf{3 4 . 4 4}$ & $\mathbf{6 . 6 7}$ & $\mathbf{0}$ & $\mathbf{0}$ \\
\hline
\end{tabular}

Berdasarkan Tabel 9, dilihat dari keanekaragaman produk pada masing-masing tiga supermarket 20 orang dari responden Multimart sebesar $66.67 \%$ sangat setuju bahwa produk pertanian di Multimart memiliki keanekaragaman. Multimart termasuk supermarket skala lokal yang terletak di pusat kota dengan lokasi yang strategis dan produk beraneka ragam sehingga banyak pembeli sehingga menjadi sirkulai produk. Sehingga banyak konsumen maka produk akan laku, setelah laku akan diganti lagi produk yang segar dan sehingga akan beraneka ragam.

Sedangkan dilihat dari seluruh responden supermarket, 52 orang dari 90 responden $(55,6 \%)$ sangat setuju bahwa produk supermarket memiliki produk yang beraneka ragam dengan berbagai varian, tersedia juga produk lokal dan produk impor, selain produk pertanian yang ditawarkan selain komoditi pertanian terdapat juga produk non pertanian seperti wahana rekreasi.

Berdasarkan kategori jumlah kunjungan, dari hasil jawaban konsumen terbanyak pada kategori 1, yaitu 41 orang dari 90 responden (45.6 $\%)$ berkunjung 1-2 kali dalam seminggu. Dari jumlah responden yang berkunjung ke tiga supermarket, 25 responden dari 41 responden sangat setuju bahwa produk supermarket memiliki keanekaragaman produk.

\section{Penempatan Produk}

Penempatan produk sesuai jenisnya akan memudahkan konsumen menemukan produk yang ingin dicari. Pada supermarket, produk segar biasanya diletakkan di lantai 1 dan di pojok belakang dipisahkan antara produk pertanian dan non pertanian, penempatan produk dapat dilihat pada Tabel 10.

Tabel 10. Penempatan Produk

\begin{tabular}{llllllll}
\hline Supermarket & Kategori & Responden & \multicolumn{5}{c}{ Persepsi Konsumen } \\
\hline & & & SS & S & N & TS & STS \\
\hline \multirow{2}{*}{ Transmart } & 1 & 14 & 10 & 4 & 0 & 0 & 0 \\
Carrefour & 2 & 10 & 7 & 3 & 0 & 0 & 0 \\
& 3 & 6 & 3 & 3 & 0 & 0 & 0 \\
\hline Jumlah & & $\mathbf{3 0}$ & $\mathbf{2 0}$ & $\mathbf{1 0}$ & $\mathbf{0}$ & $\mathbf{0}$ & $\mathbf{0}$ \\
\hline \multirow{2}{*}{ Hypermart } & 1 & 13 & 8 & 5 & 0 & 0 & 0 \\
Mantos & 2 & 12 & 5 & 6 & 0 & 0 & 0 \\
& 3 & 5 & 3 & 2 & 0 & 0 & 0 \\
\hline Jumlah & & $\mathbf{3 0}$ & $\mathbf{1 6}$ & $\mathbf{1 3}$ & $\mathbf{0}$ & $\mathbf{0}$ & $\mathbf{0}$ \\
\hline \multirow{2}{*}{ Multimart } & 1 & 14 & 9 & 5 & 0 & 0 & 0 \\
Manado & 2 & 11 & 7 & 4 & 0 & 0 & 0 \\
& 3 & 5 & 2 & 3 & 0 & 0 & 0 \\
\hline Jumlah & & $\mathbf{3 0}$ & $\mathbf{1 8}$ & $\mathbf{1 2}$ & $\mathbf{0}$ & $\mathbf{0}$ & $\mathbf{0}$ \\
\hline Total & & $\mathbf{9 0}$ & $\mathbf{5 5}$ & $\mathbf{3 5}$ & $\mathbf{0}$ & $\mathbf{0}$ & $\mathbf{0}$ \\
\hline Persentase (\%) & & $\mathbf{1 0 0}$ & $\mathbf{6 1 . 1 1}$ & $\mathbf{3 8 . 8 9}$ & $\mathbf{0}$ & $\mathbf{0}$ & $\mathbf{0}$ \\
\hline
\end{tabular}


Berdasarkan Tabel 10 mengenai penempatan produk, terdapat 61.11 persen konsumen sangat setuju mengenai penempatan produk di supermarket, dan di supermarket sesuai dengan jenis produk, rakrak tertata lebih rapi, penataan produk lebih baik sehingga mudah bagi konsumen dalam pencarian produk. Pada umumnya, dari responden sebagian besar sangat setuju dengan penempatan produk di supermarket yaitu sebesar 61.11 persen, bahwa penempatan produk sudah sesuai dengan jenis sehingga lebih mudah untuk mencari produk yang dibutuhkan.

\section{Mutu dan Kesegaran Produk}

Supermarket menyediakan kualitas produk lebih segar, bersih dan terseleksi seperti buah, sayuran, dan daging tidak mudah rusak dan tetap terjaga kesegarannya. Konsumen memilih produk yang segar dengan kualitas baik. Tanggapan konsumen mengenai mutu dan kesegaran produk pada tiga supermarket dapat dilihat pada Tabel 11.

Tabel 11. Mutu dan Kesegaran Produk

\begin{tabular}{|c|c|c|c|c|c|c|c|}
\hline \multirow{2}{*}{ Supermarket } & \multirow[t]{2}{*}{ Kategori } & \multirow[t]{2}{*}{ Responden } & \multicolumn{5}{|c|}{ Persepsi Konsumen } \\
\hline & & & SS & $\mathbf{S}$ & $\mathbf{N}$ & TS & STS \\
\hline Transmart & 1 & 16 & 10 & 6 & 0 & 0 & 0 \\
\hline \multirow{2}{*}{ Carrefour } & 2 & 11 & 4 & 6 & 1 & 0 & 0 \\
\hline & 3 & 3 & 2 & 1 & 0 & 0 & 0 \\
\hline Jumlah & & 30 & 16 & 14 & $\mathbf{0}$ & $\mathbf{0}$ & $\mathbf{0}$ \\
\hline Hypermart & 1 & 13 & 6 & 5 & 2 & 0 & 0 \\
\hline \multirow[t]{2}{*}{ Mantos } & 2 & 12 & 5 & 6 & 1 & 0 & 0 \\
\hline & 3 & 5 & 3 & 2 & 0 & 0 & 0 \\
\hline Jumlah & & 30 & 14 & 13 & 3 & $\mathbf{0}$ & $\mathbf{0}$ \\
\hline Multimart & 1 & 13 & 10 & 3 & 0 & 0 & 0 \\
\hline \multirow[t]{2}{*}{ Manado } & 2 & 14 & 8 & 4 & 0 & 0 & 0 \\
\hline & 3 & 5 & 4 & 1 & 0 & 0 & 0 \\
\hline Jumlah & & 30 & 22 & 8 & $\mathbf{0}$ & $\mathbf{0}$ & $\mathbf{0}$ \\
\hline Total & & 90 & 55 & 31 & 4 & $\mathbf{0}$ & 0 \\
\hline Persentase (\%) & & 100 & 61.11 & 34.4 & 4.4 & 0 & $\mathbf{0}$ \\
\hline
\end{tabular}

Berdasarkan Tabel 11, dilihat dari persepsi konsumen mengenai mutu dan kesegaran produk pada masing-masing tiga supermarket Transmart Carrefour, Hypermart Mantos, dan Multimart Manado terdapat 22 orang dari 30 responden multimart atau sebesar $73.3 \%$ sangat setuju bahwa produk di multimart memiliki kesagaran produk dengan mutu produk lebih baik. Hal ini dikarenakan produk yang segar dengan kualitas baik maka cepat laku dan akan berputar lagi dengan produk yang baru sehingga tetap terlihat segar.Kesegaran produk berhubungan dengan keanekaragaman produk, dimana keanekaragaman produk di multimart menempati jumlah tanggapan terbanyak, hal ini berhubungan dengan mutu dan kesegaran produk yang tetap terjaga.

Pada atribut kemudahan berbelanja, dalam kuesioner diwakili oleh tiga indikator. Untuk mengetahui jawaban-jawaban responden dapat dilihat pada Tabel 12 .

Tabel 12. Rekapitulasi Atribut Produk

\begin{tabular}{|c|c|c|c|c|c|c|c|}
\hline \multirow[t]{2}{*}{ No } & \multirow[t]{2}{*}{ Produk } & \multicolumn{5}{|c|}{ Persepsi Konsumen } & \multirow[t]{2}{*}{ Jumlah } \\
\hline & & SS & $\mathbf{S}$ & $\mathbf{N}$ & TS & STS & \\
\hline 1 & $\begin{array}{l}\text { Produk } \\
\text { beragam }\end{array}$ & 53 & 31 & 6 & 0 & 0 & 90 \\
\hline 2 & $\begin{array}{l}\text { Penempatan } \\
\text { produk }\end{array}$ & 55 & 35 & 0 & 0 & 0 & 90 \\
\hline 3 & $\begin{array}{l}\text { Mutu dan } \\
\text { kesegaran } \\
\text { produk }\end{array}$ & 55 & 31 & 4 & 0 & 0 & 90 \\
\hline & Jumlah & 163 & 97 & 10 & $\mathbf{0}$ & $\mathbf{0}$ & 270 \\
\hline & Persentase & 60,4 & 35,9 & 3,7 & $\mathbf{0}$ & $\mathbf{0}$ & 100 \\
\hline
\end{tabular}

Berdasarkan Tabel 12 tentang rekapitulasi tanggapan responden mengenai produk dapat dilihat bahwa:

1. Pada pernyataan diatas, tanggapan responden mengenai Produk beragam yang strategis, dari 90 responden 53 responden menyatakan sangat setuju, 31 responden menyatakan setuju, dan 6 responden menyatakan netral.

2. Pada pernyataan diatas, tanggapan responden mengenai penempatan produk, dari 90 responden 55 responden menyatakan sangat setuju, 35 responden menyatakan setuju.

3. Pada pernyataan diatas, tanggapan responden mengenai mutu dan kesegaran produk, dari 90 responden 55 responden menyatakan sangat setuju, 31 responden menyatakan setuju, 4 responden menyatakan netral.

4. Pada pernyataan diatas, persentase tanggapan responden mengenai atribut produk $60.4 \%$ responden menyatakan sangat setuju, $35.9 \%$ responden menyatakan setuju, dan $3.7 \%$ responden menyatakan netral. 


\section{Harga}

Atribut harga dalam penelitian ini terdiri dari harga produk terjangkau, harga sesuai mutu produk, dan adanya potongan harga (diskon).

\section{Harga terjangkau}

Perbedaan mencolok antara pasar tradisional dan pasar modern terletak pada harga barang yang dijual. Harga barang di pasar modern atau supermarket sudah pasti sesuai barcode sedangkan harga barang di pasar tradisional bergantung pada proses tawar-menawar sehingga tidak pasti. Tetapi biasanya harga barang pasar tradisional lebih murah dibandingkan pasar modern atau supermarket. Tanggapan konsumen komoditi pertanian di supermarket mengenai harga produk terjangkau dapat dilihat pada Tabel 13.

Tabel 13. Harga Produk Terjangkau

\begin{tabular}{|c|c|c|c|c|c|c|c|}
\hline \multirow[t]{2}{*}{ Supermarket } & \multirow[t]{2}{*}{ Kategori } & \multirow[t]{2}{*}{ Responden } & \multicolumn{5}{|c|}{ Persepsi Konsumen } \\
\hline & & & SS & $\mathbf{S}$ & $\mathbf{N}$ & TS & STS \\
\hline \multirow{3}{*}{$\begin{array}{l}\text { Transmart } \\
\text { Carrefour }\end{array}$} & 1 & 16 & 9 & 6 & 1 & 0 & 0 \\
\hline & 2 & 11 & 4 & 6 & 1 & 0 & 0 \\
\hline & 3 & 3 & 3 & 0 & 0 & 0 & 0 \\
\hline Jumlah & & 30 & 16 & 12 & 2 & $\mathbf{0}$ & 0 \\
\hline Hypermart & 1 & 13 & 5 & 7 & 1 & 0 & 0 \\
\hline \multirow[t]{2}{*}{ Mantos } & 2 & 12 & 5 & 7 & 0 & 0 & 0 \\
\hline & 3 & 5 & 2 & 3 & 0 & 0 & 0 \\
\hline Jumlah & & 30 & 12 & 17 & 1 & 0 & 0 \\
\hline Multimart & 1 & 14 & 5 & 8 & 1 & 0 & 0 \\
\hline \multirow[t]{2}{*}{ Manado } & 2 & 11 & 5 & 5 & 1 & 0 & 0 \\
\hline & 3 & 5 & 3 & 2 & 0 & 0 & 0 \\
\hline Jumlah & & 30 & 13 & 15 & 2 & $\mathbf{0}$ & 0 \\
\hline Total & & 90 & 38 & 47 & 5 & 0 & 0 \\
\hline Persentase (\%) & & 100 & 43.33 & 52.22 & 5 & $\mathbf{0}$ & o \\
\hline
\end{tabular}

Berdasarkan Tabel 13 persepsi konsumen mengenai harga produk terjangkau, pada supermaket Multimart ada 15 responden (50\%) menjawab setuju bahwa harga produk terjangkau. Sedangkan, dilihat dari jumlah respomden yang berkunjung ke tiga supermarket dengan jumlah kunjungan 1-2 kali dalam seminggu, sebanyak 21 orang dari 47 responden $(48.9 \%)$ menjawab setuju bahwa harga produk di supermarket terjangkau. Hal ini karena sebagian besar konsumen yang berkunjung ke supermarkettermasuk konsumen kelas menengah ke atas yang memiliki pendapatan > Rp. 3.500.000. Dan ada sebagian responden yaitu 5 orang $(5.56 \%)$ menjawab netral bahwa harga di pasar tradisional atau di pedagang-pedagang keliling lebih murah dibandingkan harga yang ditetapkan supermarket.

\section{Harga Sesuai Mutu Produk}

Ada hubungan erat antara mutu suatu produk dengan kepuasan pelanggan serta keuntungan industri. Mutu yang lebih tinggi menghasilkan kepuasan pelanggan yang lebih tinggi, sekaligus mendukung harga yang lebih tinggi dan sering juga biaya lebih rendah. Sebagian konsumen lebih menyukai berbelanja produk dengan mutu yang lebih baik walaupun harga lebih tinggi, tipe konsumen ini lebih mementingkan kualitas suatu produk. Persepsi konsumen mengenai harga sesuai mutu produk dapat dilihat pada Tabel 14 .

Tabel 14. Harga Sesuai Mutu Produk

\begin{tabular}{llllllll}
\hline Supermarket & Kategori & Responden & \multicolumn{6}{c}{ Persepsi Konsumen } \\
\hline & & & SS & S & N & TS & STS \\
\hline Transmart & 1 & 16 & 11 & 5 & 0 & 0 & 0 \\
Carrefour & 2 & 11 & 2 & 7 & 0 & 0 & 0 \\
& 3 & 3 & 3 & 0 & 0 & 0 & 0 \\
\hline Jumlah & & $\mathbf{3 0}$ & $\mathbf{1 6}$ & $\mathbf{1 2}$ & $\mathbf{0}$ & $\mathbf{0}$ & $\mathbf{0}$ \\
\hline & & & & & & & \\
\hline Hypermart & 1 & 13 & 6 & 6 & 1 & 0 & 0 \\
Mantos & 2 & 12 & 5 & 6 & 1 & 0 & 0 \\
& 3 & 5 & 2 & 3 & 0 & 0 & 0 \\
\hline Jumlah & & $\mathbf{3 0}$ & $\mathbf{1 3}$ & $\mathbf{1 5}$ & $\mathbf{2}$ & $\mathbf{0}$ & $\mathbf{0}$ \\
\hline & & & & & & & \\
\hline Multimart & 1 & 14 & 7 & 7 & 0 & 0 & 0 \\
Manado & 2 & 11 & 5 & 5 & 1 & 0 & 0 \\
& 3 & 5 & 4 & 1 & 0 & 0 & 0 \\
\hline Jumlah & & $\mathbf{3 0}$ & $\mathbf{1 6}$ & $\mathbf{1 3}$ & $\mathbf{1}$ & $\mathbf{0}$ & $\mathbf{0}$ \\
\hline \multicolumn{1}{l}{ Total } & & $\mathbf{9 0}$ & $\mathbf{4 5}$ & $\mathbf{4 0}$ & $\mathbf{5}$ & $\mathbf{0}$ & $\mathbf{0}$ \\
\hline Persentase(\%) & & $\mathbf{1 0 0}$ & $\mathbf{5 0}$ & $\mathbf{4 4 . 4}$ & $\mathbf{5 . 6}$ & $\mathbf{0}$ & $\mathbf{0}$ \\
\hline
\end{tabular}

Berdasarkan Tabel 14 persepsi konsumen mengenai harga produk sesuai dengan mutu produk, dilihat dari masing-masing supermarket, 20 orang dari 30 responden atau sebesar $66,7 \%$ dari responden yang berbelanja komoditi pertanian di Transmart Carrefour menjawab sangat setuju bahwa harga yang ditetapkan supermarket sesuai mutu produk. Dilihat dari karakteristik responden pada bagian pendapatan bahwa pendapatan reponden yang berkunjung ke supermarket yaitu konsumen menengah keatas yang lebih melihat kualitas daripada kuantitas.

Dilihat dari jumlah respomden yang berkunjung ke tiga supermarket dengan jumlah kunjungan 1-2 kali dalam seminggu sebanyak 23 orang dari 49 orang responden $(47 \%)$ sangat setuju bahwa harga produk di supermarket terjangkau, walaupun beberapa responden yaitu 3 orang menjawab netral bahwa produk di pasar tradisional lebih bermutu dan lebih segar dibandingkan harga yang ditetapkan supermarket. 


\section{Adanya Potongan Harga}

Supermarket biasanya menawarkan kartu diskon untuk pembelanjaan produk tertentu. Misalnya konsumen yang berbelanja di Transmart Carrefour, konsumen akan mendapatkan diskon 10 \% ketika bertransaksi menggunakan kartu kredit Bank Mega. Berbelanja di Hypermart dengan memiliki kartu Hicard, kartu khusus pelanggan Hypermart dan promo diskon untuk $10 \%$ untuk semua produk fresh.Sedangkan di Multimart dengan kartu debit BNI Multimart mendapat diskon $10 \%$. Pada umumnya konsumen akan senang berbelanja di supermarket karena menawarkan berbagai macam promo termasuk untuk komoditi pertanian. Tanggapan konsumen mengenai potongan harga dapat dilihat pada Tabel 15.

Tabel 15. Adanya Potongan Harga

\begin{tabular}{llllllll}
\hline Supermarket & Kategori & Responden & \multicolumn{5}{c}{ Persepsi Konsumen } \\
\hline & & & SS & S & N & TS & STS \\
\hline Transmart & 1 & 16 & 10 & 6 & 0 & 0 & 0 \\
Carrefour & 2 & 11 & 8 & 3 & 0 & 0 & 0 \\
& 3 & 3 & 2 & 1 & 0 & 0 & 0 \\
\hline Jumlah & & $\mathbf{3 0}$ & $\mathbf{1 8}$ & $\mathbf{1 0}$ & $\mathbf{0}$ & $\mathbf{0}$ & $\mathbf{0}$ \\
\hline & & & & & & & \\
\hline \multirow{2}{*}{ Hypermart } & 1 & 13 & 5 & 6 & 2 & 0 & 0 \\
Mantos & 2 & 12 & 7 & 5 & 0 & 0 & 0 \\
& 3 & 5 & 4 & 1 & 0 & 0 & 0 \\
\hline Jumlah & & $\mathbf{3 0}$ & $\mathbf{1 6}$ & $\mathbf{1 2}$ & $\mathbf{2}$ & $\mathbf{0}$ & $\mathbf{0}$ \\
\hline & & & & & & & \\
\hline Multimart & 1 & 14 & 6 & 6 & 2 & 0 & 0 \\
Manado & 2 & 11 & 5 & 5 & 1 & 0 & 0 \\
& 3 & 5 & 4 & 1 & 0 & 0 & 0 \\
\hline Jumlah & & $\mathbf{3 0}$ & $\mathbf{1 5}$ & $\mathbf{1 2}$ & $\mathbf{3}$ & $\mathbf{0}$ & $\mathbf{0}$ \\
\hline \multicolumn{1}{l}{ Total } & & $\mathbf{9 0}$ & $\mathbf{4 9}$ & $\mathbf{3 4}$ & $\mathbf{7}$ & $\mathbf{0}$ & $\mathbf{0}$ \\
\hline Persentase (\%) & & $\mathbf{1 0 0}$ & $\mathbf{5 4 . 4 4}$ & $\mathbf{3 7 . 7 8}$ & $\mathbf{7 . 7 8}$ & $\mathbf{0}$ & $\mathbf{0}$ \\
\hline
\end{tabular}

Berdasarkan Tabel 15 persepsi responden mengenai adanya potongan harga, tanggapan responden sebesar $54.4 \%$ sangat setuju dan lebih banyak di Transmart Carrefour menjawab sangat setuju bahwa lebih menyukai berbelanja di supermarket karena adanya potongan harga (diskon).

Dilihat dari jumlah respomden yang berkunjung ke tiga supermarket dengan jumlah kunjungan 1-2 kali dalam seminggu, sebanyak 18 orang dari 49 orang responden $(36.7 \%$ ) sangat setuju bahwa di supermarket transmart carrefour tersedia otongan harga bagi pelanggan yang menggunakan kartu member.

Konsumen lebih menyukai adanya potongan harga di supermarket misalnya berbelanja di transmart dengan menggunakan kartu bank mega akan mendapatkan diskon (potongan harga). Selain itu, konsumen lebih tertarik berbelanja ke supermarket karena adanya promo-promo produk lain selain produk pertanian.
Pada atribut harga, dalam kuesioner diwakili oleh tiga indikator.Untuk mengetahui jawaban-jawaban responden dapat dilihat pada Tabel 16.

\begin{tabular}{|c|c|c|c|c|c|c|c|}
\hline \multirow[t]{2}{*}{ No. } & \multirow[t]{2}{*}{ Harga } & \multicolumn{5}{|c|}{ Persepsi Konsumen } & \multirow[t]{2}{*}{ Jumlah } \\
\hline & & SS & $\mathbf{S}$ & $\mathbf{N}$ & TS & $\begin{array}{l}\text { ST } \\
\text { S }\end{array}$ & \\
\hline 1 & $\begin{array}{l}\text { Harga } \\
\text { terjangkau }\end{array}$ & 41 & 44 & 5 & 0 & 0 & 90 \\
\hline 2 & $\begin{array}{l}\text { Harga } \\
\text { sesuai } \\
\text { mutu } \\
\text { produk }\end{array}$ & 47 & 40 & 3 & 0 & 0 & 90 \\
\hline 3 & $\begin{array}{l}\text { Adanya } \\
\text { potongan } \\
\text { harga }\end{array}$ & 36 & 48 & 6 & 0 & 0 & 90 \\
\hline & Jumlah & 124 & 132 & 14 & 0 & 0 & 270 \\
\hline & Persentase (\%) & 45,9 & 48,8 & 5,3 & $\mathbf{0}$ & $\mathbf{0}$ & 100 \\
\hline
\end{tabular}

Berdasarkan Tabel 16 tentangrekapitulasi tanggapan responden mengenai harga dapat dilihat bahwa:

1. Pada pernyataan diatas, tanggapan responden mengenai harga terjangkau yang strategis, dari 90 responden 41 responden menyatakan sangat setuju, 44 responden menyatakan setuju, dan 5 responden menyatakan netral.

2. Pada pernyataan diatas, tanggapan responden mengenai harga sesuai mutu produk, dari 90 responden 47 responden menyatakan sangat setuju, 40responden menyatakan setuju, dan 3 resoponden menyatakan netral.

3. Pada pernyataan diatas, tanggapan responden mengenai adanya potongan harga, dari 90 responden 36 responden menyatakan sangat setuju, 48 responden menyatakan setuju, 6 responden menyatakan netral.

4. Pada pernyataan diatas, persentase tanggapan responden mengenai harga 45.9 $\%$ responden menyatakan sangat setuju, $48.8 \%$ responden menyatakan setuju, dan $5.3 \%$ responden menyatakan netral.

\section{Fisik Swalayan}

Termasuk dalam bentuk fisik antara lain tata letak ruang, kebersihan ruangan, dan kelancaran arus berbelanja. 


\section{Tata Letak Ruang}

Pengecer akan merancang tata letak dari semua kegunaan ruangan di supermarket, termasuk di dalamnya perlengkapan tetap supermarket, penyusunan barang-barang dan area yang tidak untuk menjual. Dapat dilihat tanggapan konsumen mengenai tata letak ruang pada Tabel 17.

Tabel 17. Tata Letak Ruang

\begin{tabular}{|c|c|c|c|c|c|c|c|}
\hline \multirow[t]{2}{*}{ Supermarket } & \multirow[t]{2}{*}{ Kategori } & \multirow[t]{2}{*}{ Responden } & \multicolumn{5}{|c|}{ Persepsi Konsumen } \\
\hline & & & SS & $\mathbf{S}$ & $\mathbf{N}$ & TS & STS \\
\hline Transmart & 1 & 16 & 10 & 6 & 0 & 0 & 0 \\
\hline \multirow[t]{2}{*}{ Carrefour } & 2 & 11 & 8 & 3 & 0 & 0 & 0 \\
\hline & 3 & 3 & 2 & 1 & 0 & 0 & 0 \\
\hline Jumlah & & 30 & 18 & 10 & $\mathbf{0}$ & $\mathbf{0}$ & $\mathbf{0}$ \\
\hline Hypermart & 1 & 13 & 8 & 5 & 0 & 0 & 0 \\
\hline \multirow[t]{2}{*}{ Mantos } & 2 & 12 & 8 & 4 & 0 & 0 & 0 \\
\hline & 3 & 5 & 4 & 1 & 0 & 0 & 0 \\
\hline Jumlah & & 30 & 20 & 10 & $\mathbf{0}$ & $\mathbf{0}$ & $\mathbf{0}$ \\
\hline Multimart & 1 & 14 & 8 & 6 & 0 & 0 & 0 \\
\hline \multirow[t]{2}{*}{ Manado } & 2 & 11 & 5 & 6 & 0 & 0 & 0 \\
\hline & 3 & 5 & 2 & 3 & 0 & 0 & 0 \\
\hline Jumlah & & 30 & 15 & 15 & $\mathbf{0}$ & $\mathbf{0}$ & $\mathbf{0}$ \\
\hline Total & & 90 & 55 & 35 & $\mathbf{0}$ & $\mathbf{0}$ & $\mathbf{0}$ \\
\hline Persentase (\%) & & 100 & 61.11 & 38.89 & $\mathbf{0}$ & $\mathbf{0}$ & $\mathbf{0}$ \\
\hline
\end{tabular}

Berdasarkan Tabel 17 persepsi konsumen mengenai tata letak ruang pada masing-masing supermarket yaitu 12 orang $(36.7 \%)$ dari responden Transmart menjawab sangat setuju bahwa tata letak ruang lebih rapi dilihat dari penataan produk dan ruangan. Berdasarkan keseluruhan responden supermarket, 55 responden $(61.11 \%)$ sangat setuju bahwa di tiga supermarket di atas, tata letak ruang lebih karena di supermarket ditata lebih menarik, beraturan per lantai, posisi rak tidak sempit, produk diletakkan berdasarkan jenis.

Dari jumlah responden yang berkunjung ke supermarket, dengan jumlah kunjungan 1-2 kali dalam seminggu, 28 dari 56 orang $(50 \%)$ dari responden supermarket sangat setuju bahwa tata letak ruang lebih baik karena termasuk skala internasional sehingga penaataannya lebih baik.

\section{Kebersihan Ruangan}

Ruangan yang bersih akan menciptakan suasana yang nyaman untuk berbelanja, karena konsumen akan mencari barang kebutuhannya. Sebagian konsumen memilih berbelanja di pasar modern dibanding pasar tradisional karena suasana pasar yang lebih bersih dan nyaman, sehingga tanggapan konsumen berdasarkan kategori jumlah kunjungan dapat dilihat pada Tabel 18.
Tabel 18. Kebersihan Ruangan

\begin{tabular}{|c|c|c|c|c|c|c|c|}
\hline \multirow[t]{2}{*}{ Supermarket } & \multirow[t]{2}{*}{ Kategori } & \multirow[t]{2}{*}{ Responden } & \multicolumn{5}{|c|}{ Persepsi Konsumen } \\
\hline & & & SS & $\mathbf{S}$ & $\mathbf{N}$ & TS & STS \\
\hline \multirow{3}{*}{$\begin{array}{l}\text { Transmart } \\
\text { Carrefour }\end{array}$} & 1 & 16 & 9 & 7 & 0 & 0 & 0 \\
\hline & 2 & 11 & 7 & 4 & 0 & 0 & 0 \\
\hline & 3 & 3 & 2 & 1 & 0 & 0 & 0 \\
\hline Jumlah & & 30 & 18 & 12 & $\mathbf{0}$ & $\mathbf{0}$ & $\mathbf{0}$ \\
\hline \multirow{3}{*}{$\begin{array}{l}\text { Hypermart } \\
\text { Mantos }\end{array}$} & 1 & 13 & 6 & 7 & 0 & 0 & 0 \\
\hline & 2 & 12 & 7 & 5 & 0 & 0 & 0 \\
\hline & 3 & 5 & 2 & 3 & 0 & 0 & 0 \\
\hline Jumlah & & 30 & 15 & 15 & $\mathbf{0}$ & $\mathbf{0}$ & $\mathbf{0}$ \\
\hline \multirow{3}{*}{$\begin{array}{l}\text { Multimart } \\
\text { Manado }\end{array}$} & 1 & 14 & 7 & 7 & 0 & 0 & 0 \\
\hline & 2 & 11 & 7 & 4 & 0 & 0 & 0 \\
\hline & 3 & 5 & 2 & 3 & 0 & 0 & 0 \\
\hline Jumlah & & 30 & 16 & 14 & 0 & $\mathbf{0}$ & $\mathbf{0}$ \\
\hline Total & & 90 & 49 & 41 & $\mathbf{0}$ & $\mathbf{0}$ & $\mathbf{0}$ \\
\hline Persentase (\%) & & 100 & $\mathbf{5 4 . 4 4}$ & 45.56 & $\mathbf{0}$ & $\mathbf{0}$ & $\mathbf{0}$ \\
\hline
\end{tabular}

Berdasarkan Tabel 18 persepsi konsumen mengenai kebersihan ruangan supermarket, dilihat dari tanggapan konsumen pada masing-masing supermarket 10 orang (33.3\%) dari responden Transmart carrefour sangat setuju bahwa kebersihan ruangan selalu bersih. Berdasarkan keseluruhan responden supermarket, 51 orang dari 90 responden (56.7 $\%$ ) sangat setuju bahwa di Transmart Carrefour kebersihan ruangan lebih bersih den rapi. Dari jumlah responden yang berkunjung ke supermarket, dengan jumlah kunjungan 1-2 kali dalam seminggu, 28 dari 56 orang (50\%) dari responden supermarket sangat setuju bahwa tata letak ruang lebih baik karena kebersihan ruangan untuk supermarket lebih bersih dan hiegenis sehingga situasi nyaman untuk berbelanja.

\section{Kelancaran Arus Berbelanja}

Arus lalu lintas pengunjung dalam suatu supermarket seperti transaksi di kasir berpengaruh terhadap keputusan pembelian ulang. Konsumen akan berbelanja kembali ke suatu supermarket karena suasananya nyaman dan kelancaran arus dalam berbelanja yang tidak berdesak-desakan. Tanggapan konsumen terhadap kelancaran arus dalam berbelanja di supermarket Transmart Carrefour, Hypermart Mantos, dan Multimart dapat dilihat pada Tabel 19. 
Tabel 19. Kelancaran Arus Berbelanja

\begin{tabular}{|c|c|c|c|c|c|c|c|}
\hline \multirow[t]{2}{*}{ Supermarket } & \multirow[t]{2}{*}{ Kategori } & \multirow{2}{*}{ Responden } & \multicolumn{5}{|c|}{ Persepsi Konsumen } \\
\hline & & & SS & $\mathbf{S}$ & $\mathbf{N}$ & TS & STS \\
\hline \multirow{3}{*}{$\begin{array}{l}\text { Transmart } \\
\text { Carrefour }\end{array}$} & 1 & 16 & 14 & 2 & 0 & 0 & 0 \\
\hline & 2 & 11 & 5 & 6 & 0 & 0 & 0 \\
\hline & 3 & 3 & 3 & 0 & 0 & 0 & 0 \\
\hline Jumlah & & 30 & 22 & 8 & $\mathbf{0}$ & $\mathbf{0}$ & $\mathbf{0}$ \\
\hline \multirow{3}{*}{$\begin{array}{l}\text { Hypermart } \\
\text { Mantos }\end{array}$} & 1 & 13 & 6 & 7 & 0 & 0 & 0 \\
\hline & 2 & 12 & 6 & 6 & 0 & 0 & 0 \\
\hline & 3 & 5 & 3 & 2 & 0 & 0 & 0 \\
\hline Jumlah & & 30 & 15 & 15 & $\mathbf{0}$ & $\mathbf{0}$ & $\mathbf{0}$ \\
\hline \multirow{3}{*}{$\begin{array}{l}\text { Multimart } \\
\text { Manado }\end{array}$} & 1 & 14 & 6 & 8 & 0 & 0 & 0 \\
\hline & 2 & 11 & 5 & 6 & 0 & 0 & 0 \\
\hline & 3 & 5 & 3 & 0 & 0 & 0 & 0 \\
\hline Jumlah & & 30 & 14 & 16 & $\mathbf{0}$ & $\mathbf{0}$ & $\mathbf{0}$ \\
\hline Total & & 90 & 51 & 39 & $\mathbf{0}$ & $\mathbf{0}$ & $\mathbf{0}$ \\
\hline Persentase (\%) & & 100 & 56.7 & 43.3 & 0 & $\mathbf{0}$ & $\mathbf{0}$ \\
\hline
\end{tabular}

Berdasarkan Tabel 19 persepsi konsumen pada masing-masing supermarket yaitu ada 12 orang $(40 \%)$ dari responden Transmart carrefour sangat setuju bahwa kelancaran arus berbelanja di supermarket lebih lancar. Berdasarkan keseluruhan responden supermarket, 51 orang dari 90 responden (56.7 $\%)$ sangat setuju bahwa di Transmart Carrefour arus berbelanja lebih lancar sehingga nyaman. Dari jumlah responden yang berkunjung ke supermarket, dengan jumlah kunjungan 1-2 kali dalam seminggu, 24 dari 51 orang $(47 \%)$ dari responden supermarket sangat setuju bahwa suasana kelancaran arus berbelanja di supermarket Transmart Carrefour lebih baik dibanding supermarket lain sehingga situasi nyaman untuk berbelanja.

Pada atribut kemudahan berbelanja, dalam kuesioner diwakili oleh tiga indikator. Jawaban-jawaban responden dapat dilihat pada Tabel 20.

Tabel 20. Rekapitulasi Atribut Fisik Swalayan

\begin{tabular}{|c|c|c|c|c|c|c|c|}
\hline \multirow[t]{2}{*}{ No. } & \multirow[t]{2}{*}{ Situasi } & \multicolumn{5}{|c|}{ Persepsi Konsumen } & \multirow[t]{2}{*}{ Jumlah } \\
\hline & & SS & $\mathbf{S}$ & $\mathbf{N}$ & TS & STS & \\
\hline 1 & $\begin{array}{l}\text { Tata letak } \\
\text { ruang }\end{array}$ & 55 & 35 & 0 & 0 & 0 & 90 \\
\hline 2 & $\begin{array}{l}\text { Kebersihan } \\
\text { ruangan }\end{array}$ & 49 & 41 & 0 & 0 & 0 & 90 \\
\hline \multirow[t]{3}{*}{3} & $\begin{array}{l}\text { Kelancaran } \\
\text { arus } \\
\text { berbelanja }\end{array}$ & 51 & 39 & 0 & 0 & 0 & 90 \\
\hline & Jumlah & 155 & 115 & $\mathbf{0}$ & $\mathbf{0}$ & $\mathbf{0}$ & 270 \\
\hline & Persentase & $\mathbf{5 7 , 5}$ & 42,6 & $\mathbf{0}$ & $\mathbf{0}$ & $\mathbf{0}$ & 100 \\
\hline
\end{tabular}

Berdasarkan Tabel 20, rekapitulasi tanggapan responden mengenai situasi dapat dilihat bahwa:

1. Pada pernyataan diatas, tanggapan responden mengenai tata letak ruang, dari 90 responden 55 responden menyatakan sangat setuju, 35 responden menyatakan setuju.

2. Pada pernyataan diatas, tanggapan responden mengenai kebersihan ruangan, dari 90 responden 49 responden menyatakan sangat setuju, 41 responden menyatakan setuju.

3. Pada pernyataan diatas, tanggapan responden mengenai kelancaran arus berbelanja, dari 90 responden 51 responden menyatakan sangat setuju, 39 responden menyatakan setuju.

4. Pada pernyataan diatas, persentase tanggapan responden mengenai atribut fisik swalayan $57.5 \%$ responden menyatakan sangat setuju, $42.6 \%$ responden menyatakan setuju.

\section{Pelayanan}

Atribut pelayanan terdiri dari pelayanan cepat, karyawan cermat dan handal, dan memuaskan penuh perhatian. Pelayanan yang baik dapat menciptakan kepuasan pelanggan, sehingga penting bagi pemasar dalam memeperhatikan cara memberikan pelayanan yang cepat, pelayanan memuaskan dan penuh perhatian, dan keramahan pegawai dan karyawan.

\section{Pelayanan Cepat}

Tanggapan konsumen mengenai pelayanan cepat dapat dilihat pada Tabel 21 .

Tabel 21. Pelayanan cepat

\begin{tabular}{|c|c|c|c|c|c|c|c|}
\hline \multirow{2}{*}{\multicolumn{3}{|c|}{ Supermarket KategoriResponden }} & \multicolumn{5}{|c|}{ Persepsi Konsumen } \\
\hline & & & SS & $\mathbf{S}$ & $\mathbf{N}$ & TS & STS \\
\hline \multirow{3}{*}{$\begin{array}{l}\text { Transmart } \\
\text { Carrefour }\end{array}$} & 1 & 16 & 12 & 4 & 0 & 0 & 0 \\
\hline & 2 & 11 & 8 & 3 & 0 & 0 & 0 \\
\hline & 3 & 3 & 2 & 1 & 0 & 0 & 0 \\
\hline \multicolumn{2}{|l|}{ Jumlah } & 30 & 22 & 8 & $\mathbf{0}$ & $\mathbf{0}$ & $\mathbf{0}$ \\
\hline \multirow{3}{*}{$\begin{array}{l}\text { Hypermart } \\
\text { Mantos }\end{array}$} & 1 & 13 & 5 & 7 & 1 & 0 & 0 \\
\hline & 2 & 12 & 4 & 6 & 2 & 0 & 0 \\
\hline & 3 & 5 & 1 & 2 & 2 & 0 & 0 \\
\hline \multicolumn{2}{|l|}{ Jumlah } & 30 & 10 & 15 & 5 & $\mathbf{0}$ & $\mathbf{0}$ \\
\hline Multimart & 1 & 14 & 10 & 4 & 0 & 0 & 0 \\
\hline \multirow[t]{2}{*}{ Manado } & 2 & 11 & 5 & 6 & 0 & 0 & 0 \\
\hline & 3 & 5 & 2 & 3 & 0 & 0 & 0 \\
\hline \multicolumn{2}{|l|}{ Jumlah } & 30 & 17 & 13 & $\mathbf{0}$ & $\mathbf{0}$ & $\mathbf{0}$ \\
\hline \multicolumn{2}{|l|}{ Total } & 90 & 49 & 36 & 5 & $\mathbf{0}$ & $\mathbf{0}$ \\
\hline \multicolumn{2}{|l|}{ Persentase (\%) } & 100 & 54.4 & 40 & 5.6 & $\mathbf{0}$ & $\mathbf{0}$ \\
\hline
\end{tabular}


Berdasarkan Tabel 21 dilihat dari tanggapan konsumen mengenai pelayanan pada masing-masing supermarket, ada 11 orang $(36.7 \%)$ dari responden Transmart sangat setuju bahwa pelayanan cepat dilihat dari transaksi pembayaran di kasir karena transmart tersedia 14 pintu kasir dan karyawan cepat dan tanggap dalam melayani pelanggan.dilihat dari keseluruhan responden supermarket, 49 orang dari 90 responden $(54.4 \%)$ sangat setuju bahwa di Transmart Carrefour pelayanan lebih cepat karena tersedia tempat pembayaran (kasir) lebih banyak sehingga jarang terjadi antrean yang panjang dalam pembayaran.

Dari jumlah responden yang berkunjung ke supermarket, dengan jumlah kunjungan 1-2 kali dalam seminggu, 26 dari 49 orang $(65 \%)$ dari responden supermarket sangat setuju bahwa pelayan supermarket cepat.

\section{Karyawan Cermat dan Handal}

Tanggapan responden mengenai karyawan cermat dan handal pada tiga supermarket disajikan pada Tabel 22.

Tabel 22. Karyawan Cermat dan Handal

\begin{tabular}{|c|c|c|c|c|c|c|c|}
\hline \multirow[t]{2}{*}{ Supermarket } & \multirow[t]{2}{*}{ Kategori } & \multirow[t]{2}{*}{ Responden } & \multicolumn{5}{|c|}{ Persepsi Konsumen } \\
\hline & & & SS & $\mathbf{S}$ & $\mathbf{N}$ & TS & STS \\
\hline \multirow{3}{*}{$\begin{array}{l}\text { Transmart } \\
\text { Carrefour }\end{array}$} & 1 & 16 & 11 & 5 & 0 & 0 & 0 \\
\hline & 2 & 11 & 9 & 2 & 0 & 0 & 0 \\
\hline & 3 & 3 & 2 & 1 & 0 & 0 & 0 \\
\hline Jumlah & & 30 & 22 & 8 & $\mathbf{0}$ & $\mathbf{0}$ & $\mathbf{0}$ \\
\hline \multirow{3}{*}{$\begin{array}{l}\text { Hypermart } \\
\text { Mantos }\end{array}$} & 1 & 13 & 8 & 5 & 0 & 0 & 0 \\
\hline & 2 & 12 & 5 & 7 & 0 & 0 & 0 \\
\hline & 3 & 5 & 3 & 2 & 0 & 0 & 0 \\
\hline Jumlah & & 30 & 16 & 14 & $\mathbf{0}$ & $\mathbf{0}$ & $\mathbf{0}$ \\
\hline \multirow{3}{*}{$\begin{array}{l}\text { Multimart } \\
\text { Manado }\end{array}$} & 1 & 14 & 7 & 7 & 0 & 0 & 0 \\
\hline & 2 & 11 & 4 & 7 & 0 & 0 & 0 \\
\hline & 3 & 5 & 2 & 3 & 0 & 0 & 0 \\
\hline Jumlah & & 30 & 13 & 17 & $\mathbf{0}$ & $\mathbf{0}$ & $\mathbf{0}$ \\
\hline Total & & 90 & 51 & 39 & $\mathbf{0}$ & $\mathbf{0}$ & $\mathbf{0}$ \\
\hline Persentase $(\%)$ & & 100 & 56.7 & 43.3 & $\mathbf{0}$ & $\mathbf{0}$ & $\mathbf{0}$ \\
\hline
\end{tabular}

Berdasarkan Tabel 22, dilihat dari pelayanan karyawan, tanggapan konsumen pada masing-masing supermarket 11 orang (36.7\%) dari responden Transmart sangat setuju bahwa pelayanan memuaskan dan penuh perhatian. Dilihat dari keseluruhan responden supermarket, 51 orang dari 90 responden $(56.7 \%)$ sangat setuju bahwa di supermarket pelayanan memuaskan dan penuh perhatian karena pegawai maupun karyawan melayani pelanggan dengan baik. Dari jumlah responden yang berkunjung ke supermarket, dengan jumlah kunjungan 1-2 kali dalam seminggu, 26 dari 51 orang $(50.9 \%)$ dari responden supermarket sangat setuju bahwa pelayanan memuaskan dan penuh perhatian karena mulai dari pramuniaga, security dan karyawan sampai pegawai toko ramah kepada pelanggan dalam melayani.

\section{Pelayanan Memuaskan Penuh Perhatian}

Pelayanan yang memuaskan dan penuh perhatian biasanya terdapat pada pasar modern yang biasanyanya karyawan menerapkan sistem pelayanan prima. Tanggapan konsumen mengenai pelayanan di supermarket khususnya pelayanan yang memuaskan dan penuh perhatian dapat dilihat pada Tabel 23.

Tabel 23. Pelayanan Memuaskan Penuh Perhatian

\begin{tabular}{llllllll}
\hline Supermarket & Kategori & Responden & \multicolumn{6}{c}{ Persepsi Konsumen } \\
\hline Transmart & 1 & & SS & S & N & TS & STS \\
Carrefour & 2 & 16 & 9 & 7 & 0 & 0 & 0 \\
& 3 & 11 & 9 & 2 & 0 & 0 & 0 \\
\hline Jumlah & 3 & 3 & 0 & 0 & 0 & 0 \\
\hline & & $\mathbf{3 0}$ & $\mathbf{2 1}$ & $\mathbf{9}$ & $\mathbf{0}$ & $\mathbf{0}$ & $\mathbf{0}$ \\
\hline Hypermart & 1 & 13 & 6 & 7 & 0 & 0 & 0 \\
Mantos & 2 & 12 & 6 & 6 & 0 & 0 & 0 \\
& 3 & 5 & 3 & 2 & 0 & 0 & 0 \\
\hline Jumlah & & $\mathbf{3 0}$ & $\mathbf{1 5}$ & $\mathbf{1 5}$ & $\mathbf{0}$ & $\mathbf{0}$ & $\mathbf{0}$ \\
\hline & & & & & & & \\
\hline Multimart & 1 & 14 & 9 & 5 & 0 & 0 & 0 \\
Manado & 2 & 11 & 5 & 6 & 0 & 0 & 0 \\
& 3 & 5 & 2 & 3 & 0 & 0 & 0 \\
\hline Jumlah & & $\mathbf{3 0}$ & $\mathbf{1 6}$ & $\mathbf{1 4}$ & $\mathbf{0}$ & $\mathbf{0}$ & $\mathbf{0}$ \\
\hline \multicolumn{1}{l}{ Total } & & $\mathbf{9 0}$ & $\mathbf{5 2}$ & $\mathbf{3 8}$ & $\mathbf{0}$ & $\mathbf{0}$ & $\mathbf{0}$ \\
\hline Persentase (\%) & & $\mathbf{1 0 0}$ & $\mathbf{5 7 . 8}$ & $\mathbf{4 2 . 2}$ & $\mathbf{0}$ & $\mathbf{0}$ & $\mathbf{0}$ \\
\hline
\end{tabular}

Berdasarkan Tabel 23 persepsi konsumen pada masing-masing supermarket mengenai keramahan pegawai dan karyawan, 21 orang (70 $\%$ ) dari responden Transmart sangat setuju bahwa pelayanan memuaskan dan penuh perhatian. Dilihat dari keseluruhan responden supermarket 52 orang $(57,8 \%)$ sangat setuju bahwa di supermarket keramahan pegawai dan karyawan dirasakan sangat baik oleh konsumen. Dari jumlah responden yang berkunjung ke supermarket, dengan jumlah kunjungan 1-2 kali dalam seminggu, 27 dari 54 orang $(50 \%)$ dari responden supermarket sangat setuju bahwa keramahan pegawai dan karyawan yang ada di supermarket lebih dibandingkan pasar tradisional. Pada prinsipnya pelayanan di supermarket telah menerapkan sistem pelayanan prima, yaitu melayani pelanggan dengan sebanyakbanyaknya, sehingga memberikan kepuasan bagi pelanggan. 
Pada pelayanan, dalam kuesioner diwakili oleh tiga indikator. Untuk mengetahui jawabanjawaban responden dapat dilihat pada Tabel 24.

Tabel 24. Rekapitulasi Atribut Pelayanan

\begin{tabular}{llcccccc}
\hline No. & Produk & \multicolumn{6}{c}{ Persepsi Konsumen } \\
\hline & & SS & S & N & TS & STS & Jumlah \\
\hline 1 & Pelayanan cepat & 49 & 36 & 5 & 0 & 0 & 90 \\
\hline 2 & $\begin{array}{l}\text { Karyawan } \\
\text { cermat dan } \\
\text { handal }\end{array}$ & 51 & 35 & 4 & 0 & 0 & 90 \\
\hline 3 & $\begin{array}{l}\text { Memuaskan } \\
\text { penuh perhatian }\end{array}$ & 52 & 38 & 0 & 0 & 0 & 90 \\
\hline & Jumlah & $\mathbf{1 5 2}$ & $\mathbf{1 0 9}$ & $\mathbf{9}$ & $\mathbf{0}$ & $\mathbf{0}$ & $\mathbf{2 7 0}$ \\
\hline Persentase & $\mathbf{5 6 , 3}$ & $\mathbf{4 0 , 4}$ & $\mathbf{3 . 3}$ & $\mathbf{0}$ & $\mathbf{0}$ & $\mathbf{1 0 0}$ \\
\hline
\end{tabular}

Berdasarkan Tabel 24 tentangrekapitulasi tanggapan responden mengenai pelayanan dapat dilihat bahwa:

1. Pada pernyataan diatas, tanggapan responden mengenai pelayanan cepat, dari 90 responden 49 responden menyatakan sangat setuju, 36 responden menyatakan setuju, 5 respon menyatakan netral.

2. Pada pernyataan diatas, tanggapan responden mengenai karyawan cermat dan handal, dari 90 responden 51 responden menyatakan sangat setuju, 39 responden menyatakan setuju.

3. Pada pernyataan diatas, tanggapan responden mengenai pelayan memuaskan penuh perhatian, dari 90 responden 52 responden menyatakan sangat setuju, 38 responden menyatakan setuju.

4. Pada pernyataan diatas, persentase tanggapan responden mengenai atribut pelayanan $56.3 \%$ responden menyatakan sangat setuju, $40.4 \%$ responden menyatakan setuju, dan $3.3 \%$ responden menyatakan netral.

Rekapitulasi total persentase atribut persepsi konsumen dapat dilihat pada Tabel 25.

Tabel 25. Rekapitulasi Persentase Atribut Persepsi Konsumen

\begin{tabular}{llllllll}
\hline \multirow{2}{*}{ No } & \multirow{2}{*}{ Atribut } & \multicolumn{7}{c}{ Persepsi Konsumen } & \multirow{2}{*}{ Jumlah } \\
\cline { 3 - 6 } & & SS & S & N & TS & STS & \\
\hline 1 & Kemudahan & 50,7 & 43,7 & 5,6 & 0 & 0 & 100 \\
& $\begin{array}{l}\text { dalam } \\
\text { berbelanja }\end{array}$ & & & & & & \\
2 & Produk & 60,4 & 35,9 & 3,7 & 0 & 0 & 100 \\
3 & Harga & 48,9 & 44,8 & 6,3 & 0 & 0 & 100 \\
4 & Situasi & 57,4 & 42,6 & 0,0 & 0 & 0 & 100 \\
5 & Pelayanan & 56,3 & 40,4 & 3,3 & 0 & 0 & 100 \\
\hline & Total & $\mathbf{2 7 3 , 7}$ & $\mathbf{2 0 8 , 9}$ & $\mathbf{1 7 , 4}$ & $\mathbf{0}$ & $\mathbf{0}$ & $\mathbf{5 0 0}$ \\
\hline & Rata-rata & $\mathbf{5 4 , 7}$ & $\mathbf{4 1 , 8}$ & $\mathbf{3 , 5}$ & $\mathbf{0}$ & $\mathbf{0}$ & $\mathbf{1 0 0}$ \\
\hline
\end{tabular}

\section{KESIMPULAN DAN SARAN}

\section{Kesimpulan}

Berdasarkan persepsi konsumen yang berbelanja komoditi pertanian pada supermarket di Kota Manado terhadap kelima yang mempengaruhinya, termasuk dalam kategori sangat setuju $(54,7 \%)$, setuju $(41,8 \%)$, netral $(3,5 \%)$, sedangkan kategori tidak setuju dan sangat tidak setuju tidak dipilih. Dari kategori sangat setuju, atribut produk menempati urutan pertama $(60,4 \%)$, diikuti atribut situasi $(57,4$ $\%)$, atribut pelayanan (56,3 \%), atribut kemudahan dalam berbelanja $(50,7 \%)$, dan posisi akhir atribut harga $(48,9 \%)$.

\section{Saran}

Bagi pemasar untuk mempertahankan kelima taribut tersebut, dan perlu untuk memperbaiki atribut harga agar menjangkau semua kalangan konsumen.

\section{DAFTAR PUSTAKA}

Damiati, L. Masdarini., \& M. Suriani. 2017. Perilaku Konsumen. Penerbit: PT. Raja Grafindo Persada. Depok.

Dewi, Normasari Wikan. 2013. Pengaruh Atribut Produk dan Harga Terhadap Keputusan Pembelian Bundle Handphone Smartphone Merek Blackberry 8530.Jurnal Ekonomi dan Bisnis. Vol. 1 No 4. Hal 1-20.

Faudiyah, Nurul. 2016. Pengaruh Nilai Utilitarium dan Nilai Hedonik Terhadap Keputusan Pembelian.Fakultas Ilmu Administrasi Universitas Brawijaya Malang. Jurnal Administrasi Bisnis (JAB). Vol. 36 No. 1. Hal 129-136.

Huddleston Patricia, Minahan Stela. 2011. Consumer Behavior: Woman and Shopping. Business Expert Press. New York.

Kartono, Adi M. 2007. Analisis Usaha Kecil dan Menengah. CV. Andi Offset. Yogyakarta. 
Kotler, Philip. 2008. Manajemen Pemasaran. Edisi Milenium. Terjemahan Benyamin Molan. PT: Prenhallindo. Jakarta.

Ma'aruf, 2006. Pemasaran Ritel. Gramedia Pustaka Utama. Jakarta.

Mangkunegara, A. A. Anwar Prabu. 2002. Perilaku Konsumen. Edisi Revisi. Penerbit PT. Refika Aditama. Bandung

Praditha, N. A. 2015. Analisis Hubungan Antara Karakteristik Responden dengan Faktorfaktor yang Mempengaruhi Keputusan Menjadi Member Tupprerware. Skripsi Program Studi Manajemen Fakultas Ekonomi Universitas Sanatha Dharma. Yogyakarta.

Riorini, S. V. 2001. Faktor-faktor yang Menjadi Pertimbangan Konsumen dalam Memilih Departement Store. Fakultas Ekonomi Trisakti Universitas Krida Wacana. Jurnal Meditek. Vol. 9 No 24. Hal 1-18.

Schiffman dan Kanuk, 2000. Perilaku Konsumen. Edisi Kedua. PT Indeks Gramedia. Jakarta.
Setiadi, Nugroho. 2010. Perilaku Konsumen: Perspektif Kontemporer Pada Motif, Tujuan, dan Keinginan Konsumen. Kencana Prenada Media, Jakarta.

Solomon, Michael. R. 2002. Consumer Behavior: Buying, Having, and Being. Prentice Hall. New Jersey.

Sudaryana, A. 2011.Perilaku Konsumen dalam Berbelanja Pada Supermarket di Wilayah Yogyakarta.Jurnal Akuntansi dan Manajemen.Akmenika UPY, Vol 8, 2011.6783.

Sugiarto, M. E. 2017.Faktor-faktor yang Mempengaruhi Konsumen dalam Keputusan Pembelian Buah di Freshmart Tikala Kota Manado.SkripsiProgram Studi Agribisnis Fakultas Pertanian Universitas Sam Ratulangi. Manado.

Sumarwan, Ujang. 2004. Perilaku Konsumen. Teori dan Penerapannya dalam Pemasaran. Ghalia Indonesia. Bogor.

Suryani, Tatik. 2013. Perilaku Konsumen di Era Internet. Graha Ilmu. Yogyakarta. 